\title{
بعض الصعوبات التى تحول دون تحقيق التواصل المدرسى وسبل مواجهتها
}

مخمد عبد القادر مخمد محمد حسانين

المـــؤثزة و الفعالـــة، حيـــث أن المعلومــــات و القرار ات يجب أن تمر بسرعة وكفاية إلـىى الأفر اد الذين هم في حاجة إلى المعرفة، لــذا كان توظيف وسائط التو اصل المدرسي مهمة رئيسية من مهام الإدارة المدرسية .(محمد،:

$$
\text { (VO G. } 10
$$

وترجع أهمية التو اصل المدرسي إلى

كونه عاملا مشتركا بين جميــع العمليــات المدرسية ، و هذا يتضـح من خـــلال مهامـــهـ

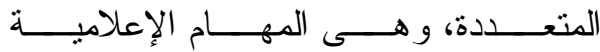
و الانضباطية، و المهـــام التكامليــة و المهـــام

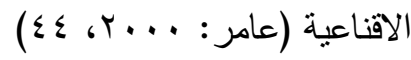

ويعتبر التو اصل المدرســى عمليــة مشتركة تسعى نحو نقل المعلومات و الفهـــ من شخص لآخر، و هذا يعنى وجود مرســل للمعلومات ومستقبل لها، ووسيلة يــتم مــن

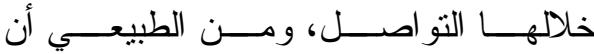
الاتصالات لا تقف عند حد نقل المعلومـــات فقط بل يجب أن يتحقق المرسل مــن تقهـــ المستقبل لها طبقا لما يبتغيه، وتسهم التغذيــة

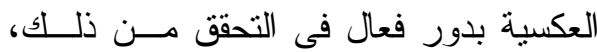

يعد التواصل أمر ا مهما لنجاح الإدارة

فى مستوياتها المختلفة وخاصـــة المـسـتوى التتفيذي أو الإجرائي حيث يستمد التواصــل أهميته فى الإدارة من المسؤولية الأولى التي تقع على عاتق المدير وهي انجاز الأعمــال من خلال الآخرين كو لان تواصل المدير مع كافة اعضاء المدرسة جزء لا يتجــز أ مـنـ العمل اليومي له. وبما أن التو اصل جزء لا يتجز أ مــن العمل اليومي للمدير فعليه أن يوظف كافــة وسائط التو اصل المدرسي التقليدية و الحديثـة و المتمنلة فى (الأو امر الثفهية و المكتوبــة النشر ات -المذكر ات و التقــارير ـالمجــالس التعليمية -الاجتماعات المدرسـية -البــاب المفتوح للرئيس -مكتب الثكاوى أو صندوق الــشكاوى ـالإذاعـــة المدرســية ــوحســة الإعلانـــات المدرســية مهلــــة المدرســـة ، . . . . . . . . . . . . . . . . . . . للك لتحقيق أعلى قدر من التفاعل و التفاهم بين العاملين بــــا يسهم فى خلق روح العمل ويعــــ التو اصــلـ المدرسي أمر ا حيويـــــــلـلإدارة المدرســية 


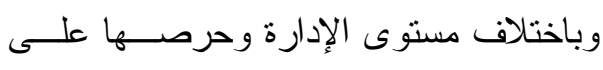

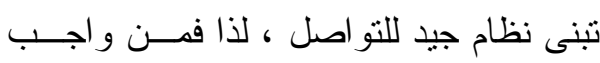

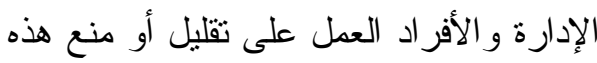

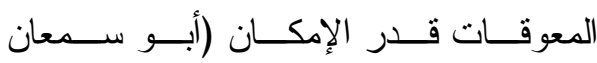
$\left(: T \Lambda_{6} T V_{6}, r+1\right)$

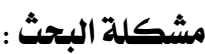

وتتعدد مشكلات التو اصل المدرســي

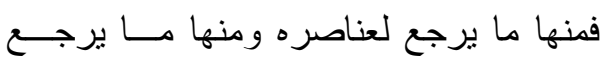
لوسائط التواصل كالاجتماعــات المدرسـية لرهية و المجالس التعليمية و النــشر ات و المـــكرات

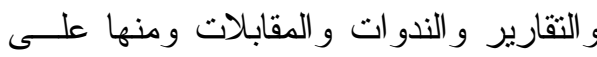
سبيل المثال تعدد القرارات التي تحدد العلاقة

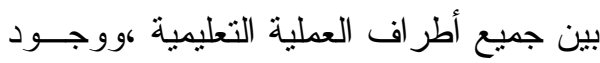
فروق فردية بين العاملين ،وكذلك التعـصب لموقف أو رأى أو وجهة نظر معينة وكذلك عدم وجود أهداف محددة ومرسومة مطلوب تحقيقها عن طريق الاتصال ،بالإضافة لعـدم إعطاء العناية والأهية لأفكار ووجهات نظر الأهر

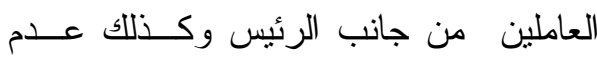
رغبة بعض العاملين في المشاركة في عملية

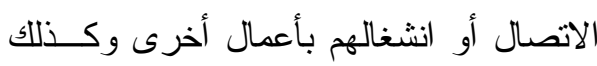

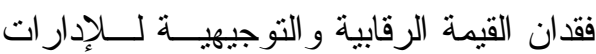
على كافة المستويات وتولى مناصب القيــادة

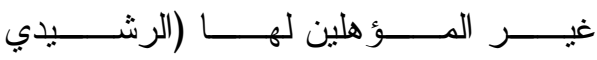

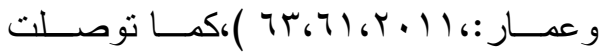

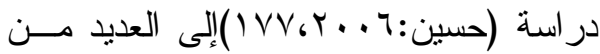

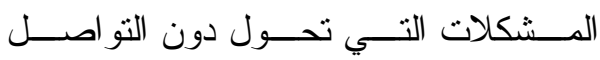

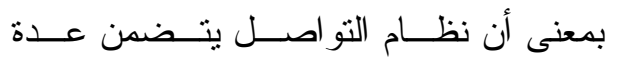
عناصر رئيسية هــي المرســل و المــستقبل و الرسالة و الوسيلة و التغذية العكسية، كما انه ونه يتم تحقيق هدف معين فى وقت ومكان محدد

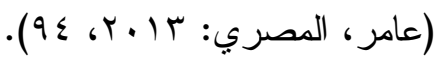
وتعتبر در اســـة عمليــات التواصــلـ

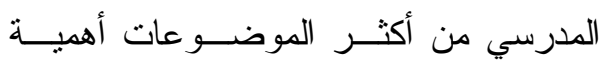

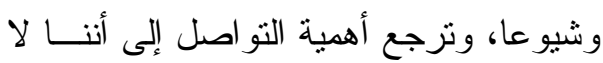

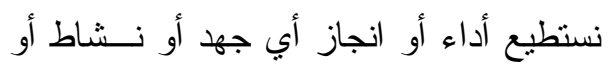

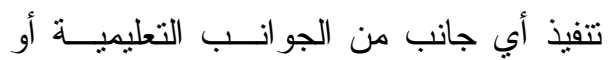

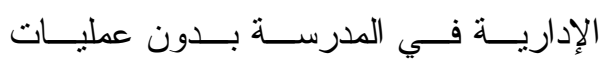

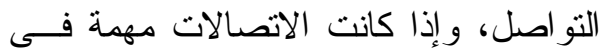

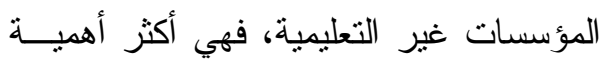
فى المؤسسات التعليمية حيث لا تمنل عملية

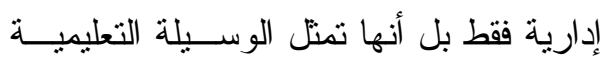

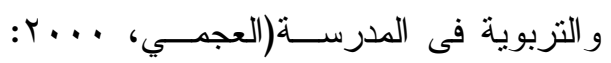

ومــن الجــدير بالــــكر أن عمليــة

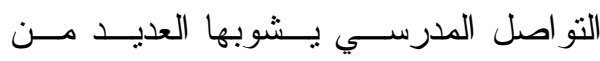

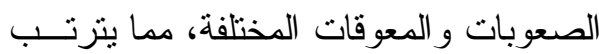

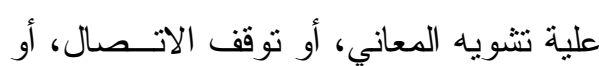

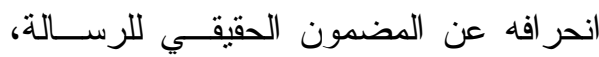
وبذلك تتأثز فاعلية التو اصل بكافة وســائطه، وتعود معوقات التو اصل على كل من الفــرد

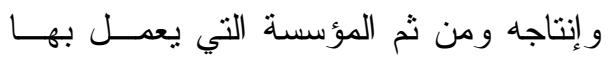

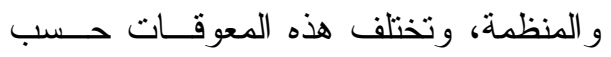

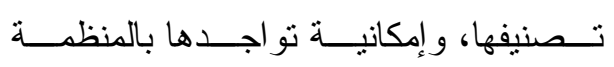




$$
\begin{aligned}
& \text { r- ما أهم الصعوبات التـى تحــول دون }
\end{aligned}
$$

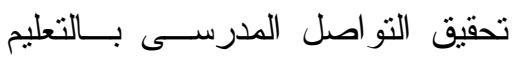

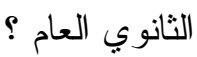

$$
\begin{aligned}
& \text { ب- ما أهم المنطلبات اللازمـــة لمواجهـــة }
\end{aligned}
$$

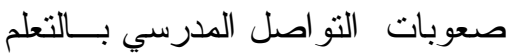

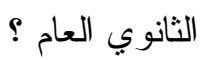

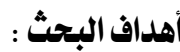

يهذف البحث الحالي لمحاولة التوصل

- توضيح الاطار المفاهيمى للتو اصـل

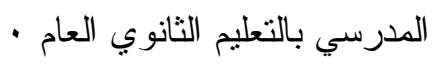

- ابر از أهم الصعوبات التى تحول دون

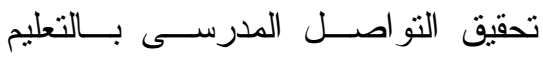

$$
\text { • الثانوي العام }
$$

- تحديد أهم المنطلبات اللازمة لمواجهة

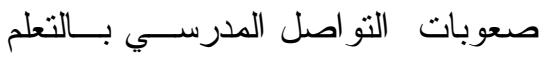

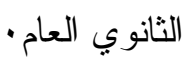

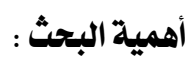

تظهر أهمية البحث في أنـــهـ بيتـــاول

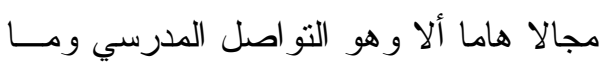

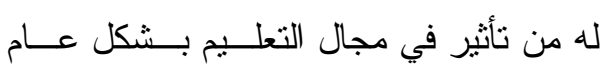
و العمليات المدرسية بشكل خاص حيث يعتبر التواصل أهم عو امل تحقيق أهداف العمليـــة التعليمية و التربوية بوجه عام، حيــث مــن اهن المتوقع أن يستقيد منها المديرين و المعلمـين ولين و الطلاب و العاملين في الحقل التربوي.

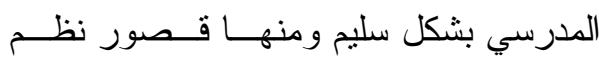

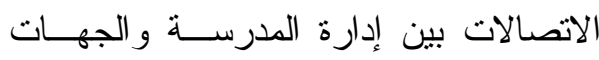
الأعلى فقط وقلة اســتقرار الجهــاز الإداري

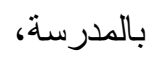

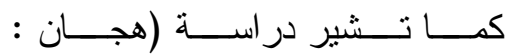

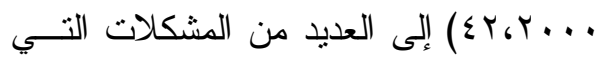
تو اجه عملية التو اصل المدرسي ومنها عـدم

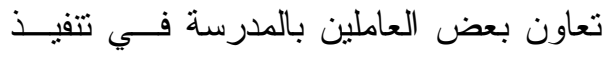
القرار ات وعدم تو افر المعلومــات الكافيـــة

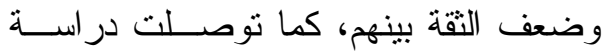

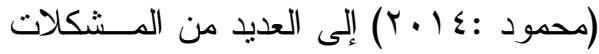

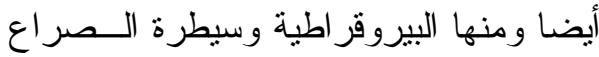
المستمر الهـام ، وتضخم الهياكل الإداريـــة وبطئ الاستجابة لمطالب التغيير و التطــــوير، التهرئ

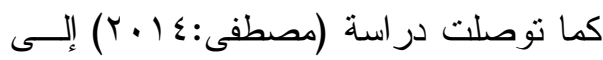
تمسك بعض المديرين بأســاليب الاتـصال التقليدية وعــدم إتاحسـة الفرصــة للابتكـــار

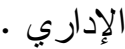

وبناءا على ما سبق فانه يمكن بلـــورة مشكلة البحث فى التساؤل الرئيسي الأتي: ما أهم الصعوبات التى تحول دون تحقيـق

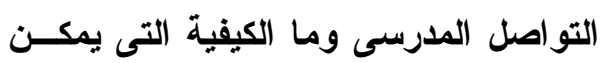
بها مواجهة تلك الصعوبات ؟ ويتفرع منه الأسئلة التالية:

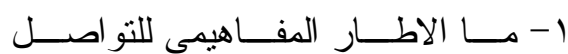
المدرسي بالتعليم الثانوي العام ؟ 


$$
\text { التعريف الإجرائي : }
$$

\section{منهج البحث :}

عبارة عن علاقات التفاعل المتبادلـــة

بين اطر اف العملية التعليمية بعضهم البعض وبين اطر اف الإدارة فيما بينهم وبينهم جميعا وذلك من اجل اتمام جميع عمليـات الادارة داخل المدرسة وبينها وبين مستويات الادارة الاعلى بشكل جيد لتحقيق الاهداف وله

الدراسات السابقة أولا الدراسات العربية : العاداسية

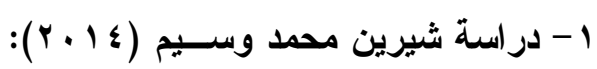

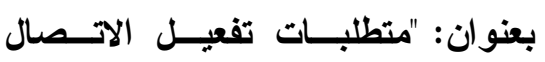

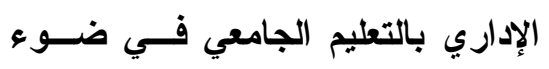
بعض المداخل الإدارية الحديثة".

و هدفت إلى إبر از أهـــم المــــاخل الإداريـــة الحديثة ونوظيفها في تفعيل الاتصال الإداري إلى الإدي ووضع تصور مقتــر ح لمتطلبــات تفعيــل

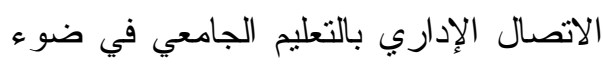
بعض المداخل الإدارية الحديثة.

واستخدمت الدراسة المنهج الوصفي و أداته الاستبانة.

وتوصلت الى اهمية الدور الحيوي

للاتصال الإداري داخل المؤسسة الجامعيــة

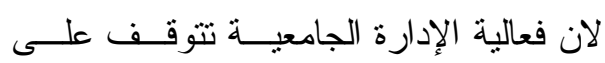

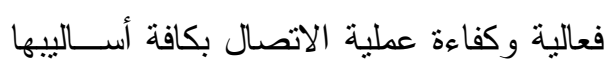
ووسائلها.
تستدعى طبيعة هذا البحث، توظيـف

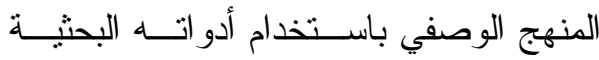

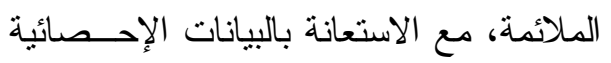

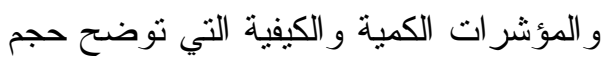

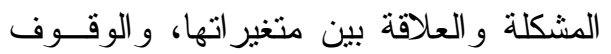

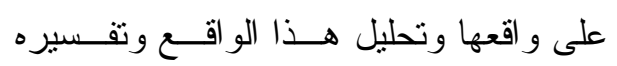
لدحاولة رصد وتقييم و اقع التو اصل المدرسي ولي ولي لئي بالتعليم الثانوي العام داخل المدرسة بين كافة وحداتها - ماته مصطلحات البحث : وحاء

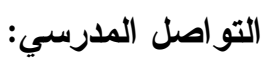
هو عبارة عن الفعاليات والاجر اءات

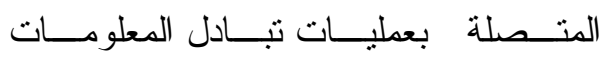
وتوزيعها على المجالات المدرسية المختلفـــة

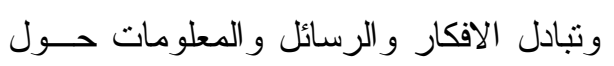
القضايا التي تشغل كافة المنصلين بالعمليـــة التعليمية و الادارية داخل المدرسة ـ (حسسين

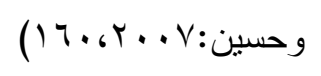

ويعرفــهـ اخـــر: بأنـــهـ مجموعـــة

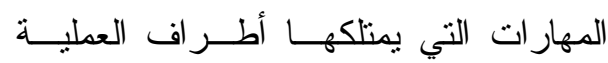
التعليمية داخل المدرسة والتي تهدف لنجاحها

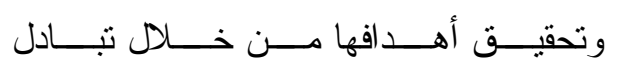

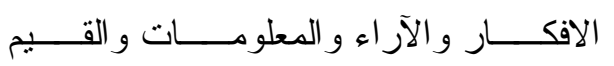

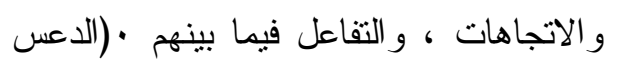
•) (: r s r. . . 9 
وذللك لتطـــوير وتقـــــم العمليــة التزبويـــة

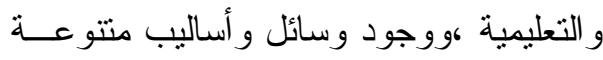
للتو اصل التربوي بين المدرسة و الأسرة ،كما

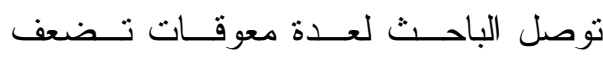
التو اصل التربوي بين الأسرة و المدرسة . لوعل r- دراســـة عـــصام رشـــــاد بــسيوني

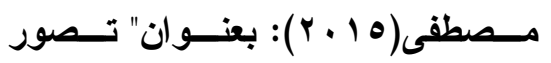
مقترح للاتصال الإداري بمدارس التعليم

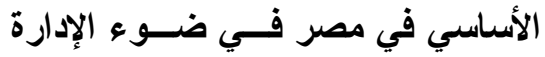
الإلكترونية " الإنية

و هدفت هذه الدر اسة إلى: " وضــع

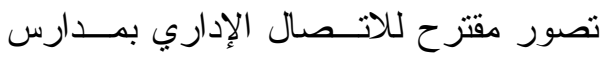
التعليم الأساسي في جمهورية مصر العربية في ضوء الإدارة الإككترونية". و واســـتخدمت الدر اســــة المــــــهج الوصفي و أداته الاستبانة. وتوصلت هذه الدراسة إلى العديد من

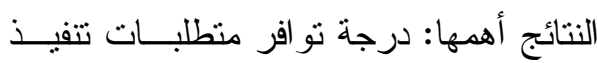

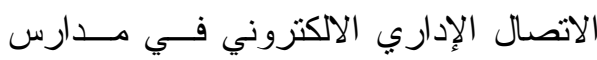

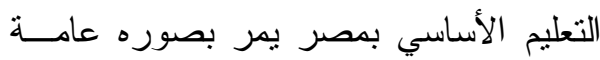

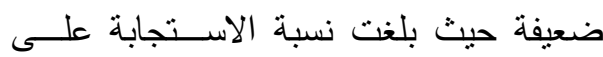

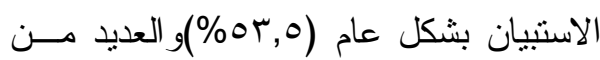

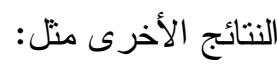
- قلة عدد مدارس التعلــيم الأساســي المنصلة بشبكات الانترنت.
ومعاناة الإدارة الجامعية في مصر

مــن العديــــــــن المــشكلات أهمهـــــا: (البيروقر اطية وسيطرة الــصر اع المـستمر

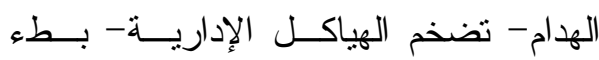
الاستجابة لمطالب التغيير و التطوير).

كما يسهم تطبيـق مســخل الإدارة الإلكترونية في تحسـين عمليــة الاتـصـال الإداري الجامعي وذللك بتفعيل الاتـصالات الرسمية وغير الرسمية.

يسهم نطبيق مدخل إدارة المعرفة في

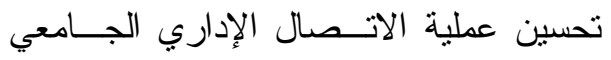
وذلك بإيجاد ذاكرة معرفية للجامعة .

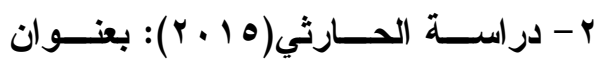
التواصل التربوي بين المدرسة و أولياء الأمور وتطبيقاته المعاصرة .

و هـــدفت إلــى إبـــر از منطلبـــات

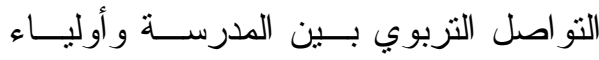
الأمور وتطبيقاته المعاصــرة مــن خــله

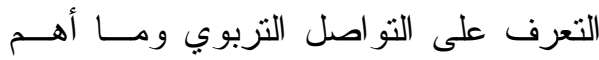
أساليب تفعيله بين المدرسة وولى الأمر ،وما

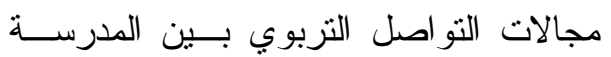
وولى الأمر وما معوقاته .

و اســـتخدمت الدر اســــة المـــــهج الوصفي التحليلي .

وتوصلت الدراســـة إلـى أهميــة

التواصل التربوي بين المدرســـة و الأســـرة الهئة 


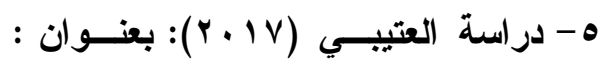
نموذج مقترح لتنمية مهارات التواصل التربوي فى ضوء جودة الأداء الوظيفي بين معلمي وموجهي التربية الموسيقية بدولة الكويت . بل معي وموجت و هدفت إلى التعـرف علـــى الو اقــع

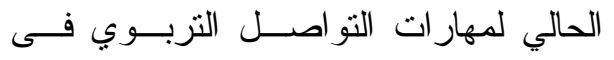

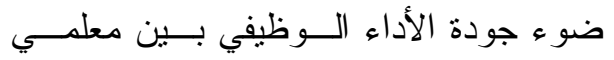

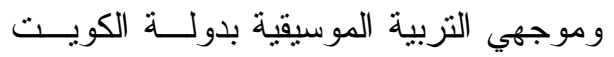

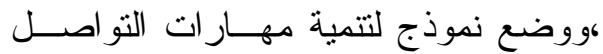

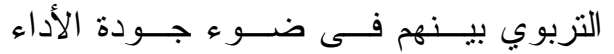

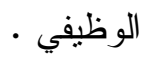

و استخدمت الدراسة المنهج الوصــي

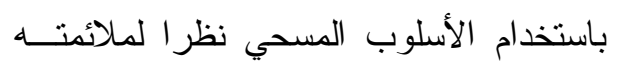
لطبيعة البحث. باسنغ م الانلو

وتوصلت الى أن مهار ات التو اصــلـل التزبوي لاى موجهي التزبية الموسيقية مـــع المعلمين و المعلمات جاءت بدرجة منوســـة لمكة

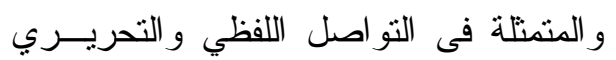

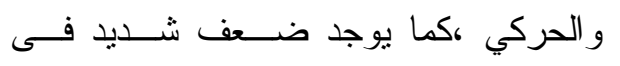
مستوى النو اصل الالكتروني ويرجع ذلك إلى ولى

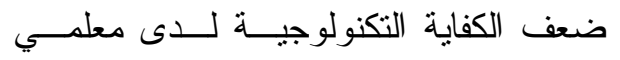

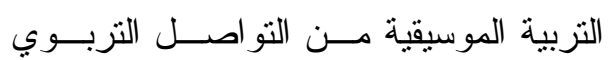

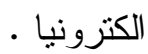

- - متمكك بعـض المــدرين بأســاليب الاتصال الإداري التقليدي.

- - معـدم إتاحسـة الفرصــة للابتكـــار

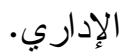

- - وكذلك ضعف الثقافـــة الالكترونيـــة وضعف منظومة الأجهزة.

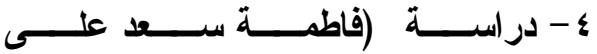

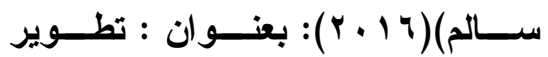

الاتصال الإداري فى إدارة التعليم العام

بليبيا فى ضوء الإدارة الاككترونية.

- - هدفت الدراسة إلى تطوير الاتـصـال

الإداري فى إدارة التعليم العام بليييــا

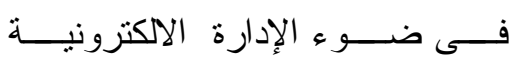

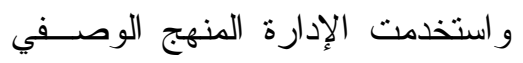

وتوصلت إلــى ان واقــع الاتـصال

الإداري بالتعليم العام بليبيا يشير إلـى الـى

العديد من جو انب الضعف ومنها :

- - صـــوبة الاتــصال وبطئـــه بــين المستويات المركزية و المحلية

- - افتقار الاتصال إلى خطوط الاتــصل

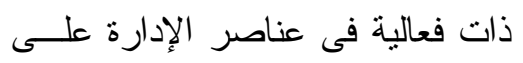
كافه المستويات

- - معف الاتصالات الإدارية بسبب قله

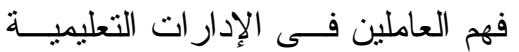

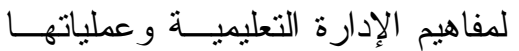


الثانوية في هولندا منل المنهج و الأسلوب في الاتصال متعدد الطرق.

واستخدمت الدراسة المنهج الوصفي

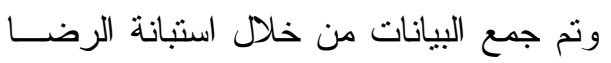

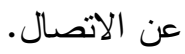

وقد خلصت هذه الدراسة إلى الكثف

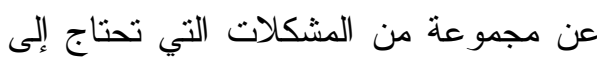
اهتمام من الإدارة ومنها ضعف المشاركة في صنع القرار مما يؤدى إلى شعور العـاملين بعدم التقدير، وقد حددت الدر اسة مــشكلات

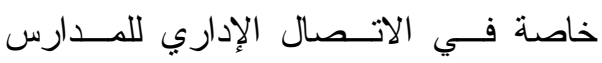

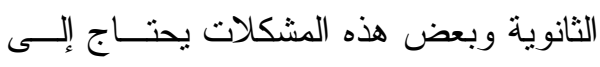
تغييرات هيكلية وتخطبط طويل المدى. r- دراسة سيفيم (7 1 • r): بعنوان: "إدارة الموارد البشرية في الكليات التعليميــة التهية بجامعات الدولة في تركيا"

و هدفت هذه الدر اسة إلى تقيــيم إدارة الموارد البشرية في كليات التربية للجامعات الحكومية في نركيا في ســياق مبــادئ إدارة

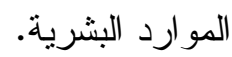

و استخدمت الدراسة التحليل الو صفى و المحتوى حيث نم جمع البيانات من خــلال مقابلات شبه منظمة، وتكون مجتمع الدراسة من(·ـ) عضو اكاديمي في كليات التربيــة

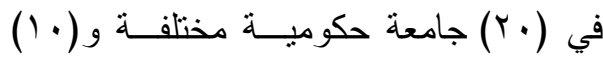
مدر اء وحدات أكاديمية في مو اقع مختلفة.

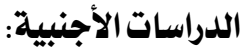

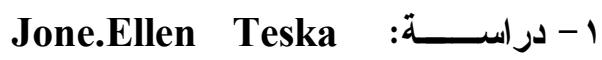

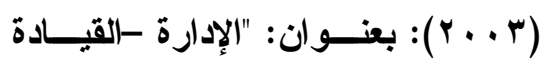

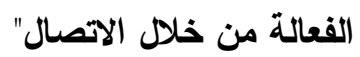

و هدفت هذه الدر اســـة إلـــى" فحــص

العلاقة بين السلوك القيادي ونمط الاتصال ".

و اعتمدت الدر اســـة علــى اســتخدام

المنهجين الكمي و الكيفي في جمــع وتحليـلـل

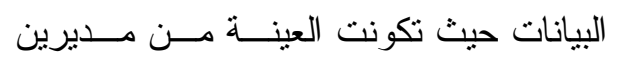

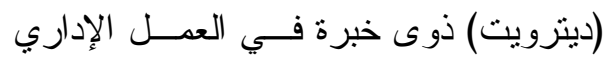
تتر اوح أعمار هم من (10 (-0. -7) عام.

وتوصلت الدراسة إلى:

- - إن نمط الاتصال الفعال يركز علــى إسى قدرة الإصغاء بتركيز الآخر .

- - إن وسائل الاتصال المستخدمة مـن

قبل المــيرين هــي اســتراتيجيات

مشتركة بينهم

- - إن أساليب و استر اتيجيات الاتــصال

المستخدمة تعكس الثخصية الفردية.

- - الصدق و الأمانة في الاتصال يعتبران

من العو امل الحاسمة الهامة في تقرير

مدى فاعليته.

r - دراسة: زويجزودى جونــــ (Zwijze)

$$
:(r \text {. q)(de Jong }
$$

وهدفت هذه الدراســـة إلــى بحــث

مجموعة من مشكلات الاتصال في المدارس لنس لنس 


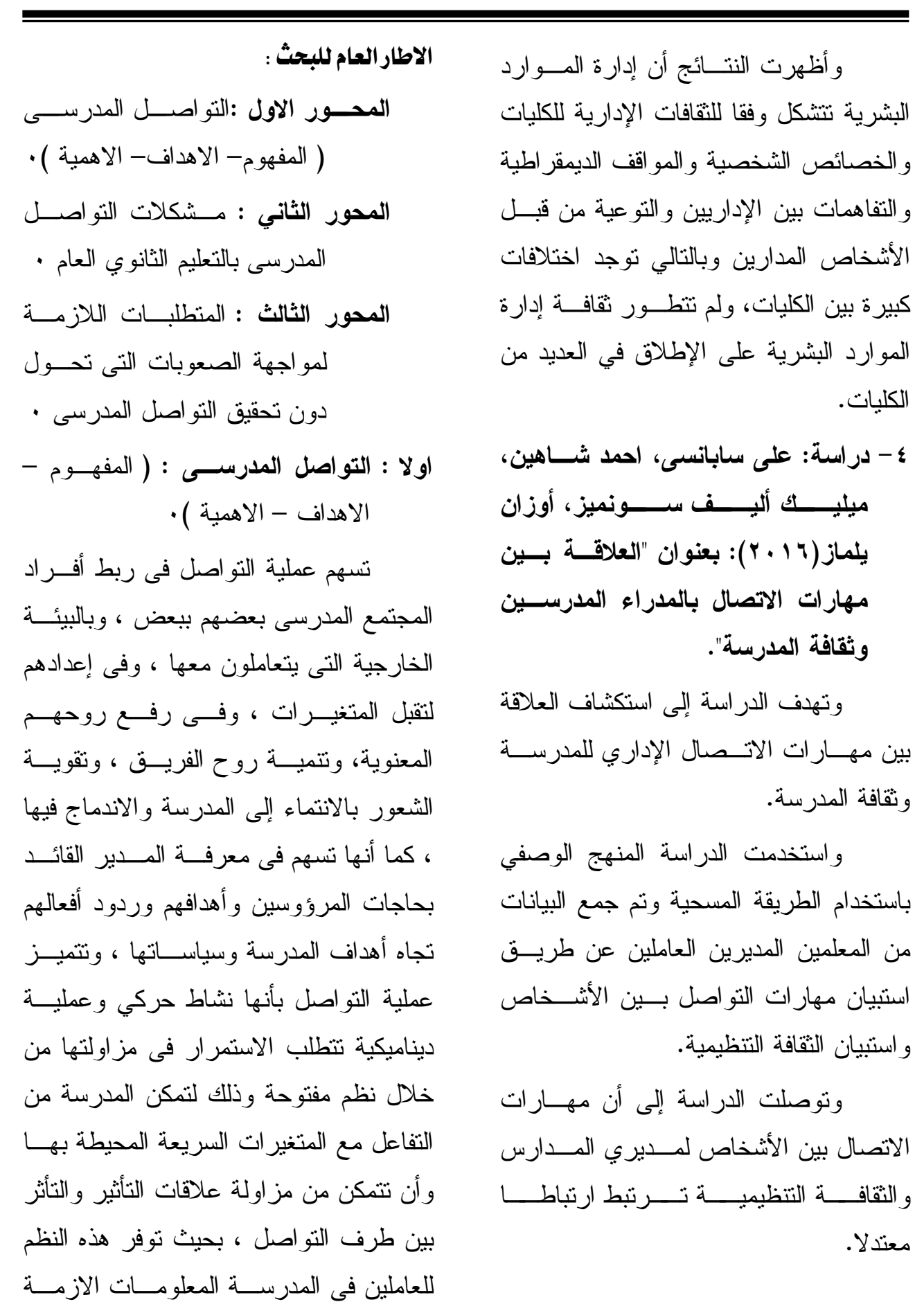


الثفهي ، أو وسائل أخرى مختلفـــة بحيــث

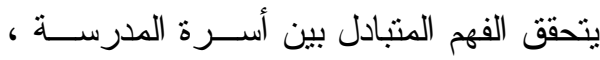

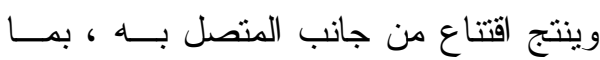

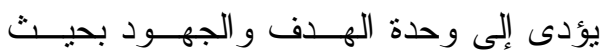

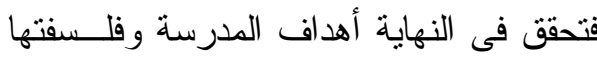

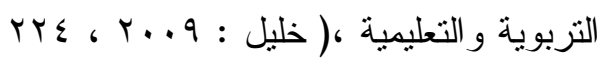

بينما يرى ( الجمال : 1| •r ، ) أن التو اصل علاقة منبادلة بين طرفين فى لائل الاتصال ( To be interconnected ) أي في في أن هناك رغبة من أحد الطرفين فى التواصل

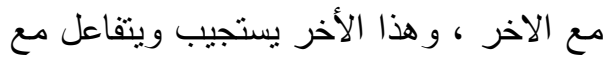

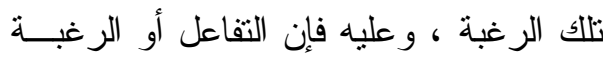
فى المشاركة تحدث من كلا الطرفين .

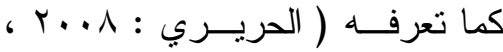

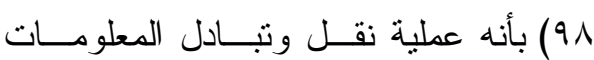
و الآر اء و التوجيهات بين الأطر اف المختلفــــة للعملية التعليمية و الاداريــة فــى المؤسـسـة المدرسية بغرض المـسـاعدة فـى تحقيـق الأهداف النزبوية .

ومما سبق فإن الدراسة الحالية تعرف

التواصل المدرسى إجرائيا باتهـ " علاقــات التفاعل المنبادلة بين اطراف العملية التعليمية بعضهم البعض وبين اطــــر اف الإدارة فيمــــا بينهم وبينهم جميعا وذللك من اجل اتمام جميع بعن عمليات الادارة داخل المدرسة وبينها وبـين ونين
لاتخاذ القرارات و إنجاز المهــام و الوجبـــات و الربط بين مـستوياتها وتــوفير الوســائل

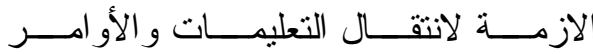
و التوجيهات بما يضمن التفاعل التــام بــين العاملين وتحقيق التز ابط بيــنهم مــن أجــل تحقيق الهـدف المـشترك .( الحريــري : . ( $9 \vee, r . . \wedge$ وفى اللغة " التو اصل " مــن الفعـلـ الماضي الثنالثي " وصل " و المضار ع منـــه " يصل " ويقال " وصل " الثيء أو "وصل " الى الثيء " وصلا " أي " بلغه و انتهى به " ، وفى الانجليزيـــة " "communication" مأخوذ من الأصل اللاتينـي( communis ) بمعنى(common) أي عام وتعنـى تبــادل و المعلومات أو الأفكار أو الأداء بين طرفين

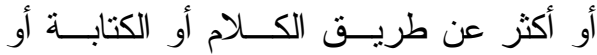
الإشارة ، و هو ايضا عملية تفاعل مسشتركة بين طرفين او أكثر لتبادل فكرة او خبرة عن

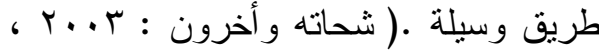
( (1) ، IV

ويعرف التواصل المدرسى بأنه نقــلـ

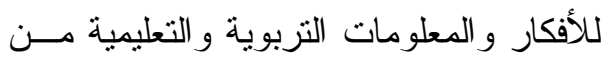
الناظر أو مدير المدرسة إلى المعلم و العكس وله

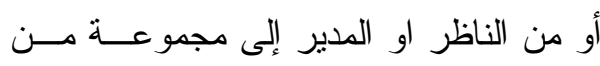

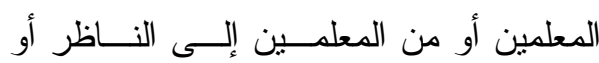

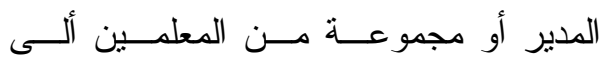
مجموعة أخرى ، سو اء بالأسلوب الكتابي أو لمعلي 
التدريب و التعامل ونقــلـ المعلومـــات و الأفكار وتبادلها للعمل على تحقيــق ونق

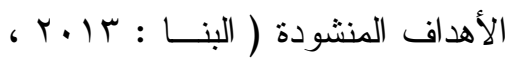
. (117 0ـ نقل الافكار و الأر اء و البيانات وتوجيه نشاط كافه أعضاء المجتمع المدرسى ولهى ولهي وحفز هم وتزويدهم بالمعلومات مسنـ اجل إنجاز بر امج العـــل المدرسـى المحققة للأهداف التزبوية و المدرسيه وتحقيق رضا المجتمع المحلى وأولياء

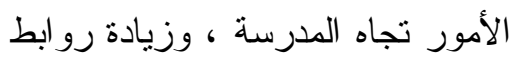

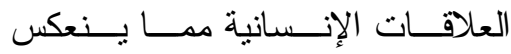
بالإيجاب على العمل المدرسى • 7- تسهيل عملية إتخاذ القرارات السليمة داخل المدرسة وتتفيذها وتتفيذ عمليات

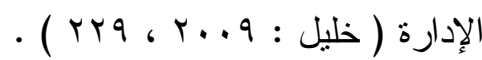
V- اعلام المرؤوسين بالأهداف المطلوب

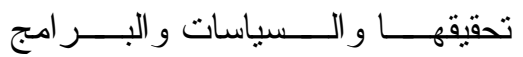
و التعليمات وكذلك اعــلام الرؤســاء بالمشكلات و المقترحات و الآر اء ( أبو النعاء ولكو

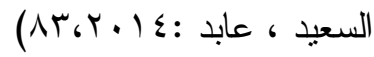

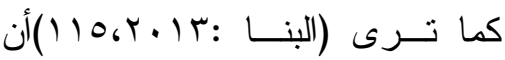
الاتصال و التو اصل الفعال داخــل المدرســـة

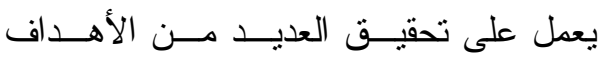
المدرسية التربوية و التعليمية منها:
مستويات الادارة الاعلى بشكل جيد لتحقيــق

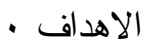
*-أهداف التواصل المدرسى : يلعب الاتصال و التو اصل دور كبيــر

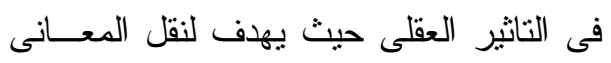

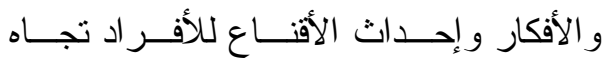

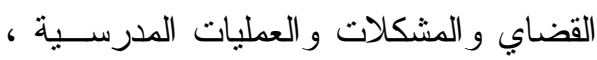
كما إنه يعمل على الإيجاد للأفـــر اد بأفكــار

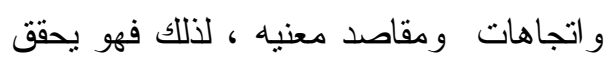
الكثير من الأهداف داخل المدرسة منها :-1 ـ زيادة فرص التعاون و التفاهم و التقـــة

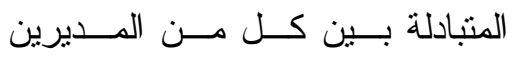
و المعلمين و الطلاب و أولياء الأمــور من أجل إكسابهم الإحتر ام فى التعامل

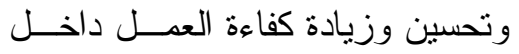

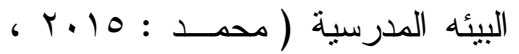
r- التأثثر المتبادل بين طرفى التواصـل من أجل تغيير السلوك أو تعديلـــة أو لون

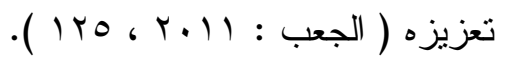
r- - ربط أفراد المجنمع المدرسى بعضهم ببعض من جهه وربطهــم بمحـبطهم الخارجى الذى يتعاملون معه من جهه

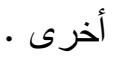

ع - ـيادة التو اصل بين العاملين من أجــل

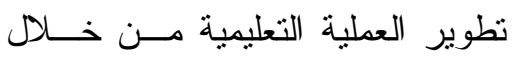


مجــــالس الابـــــاء و المعلمـــين و المجــــالس

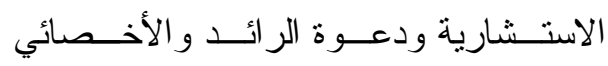

الاجتماعي لأولياء الأمور لبحث المـشكلات

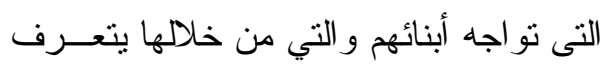

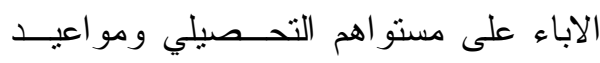

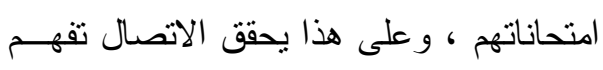

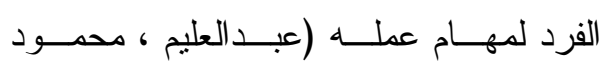
$\left(: \Sigma \Lambda_{6} \leqslant V_{6} Y_{P}\right) Y$

تبرز أهمية التو اصل فــي المدرســة

الثانوية فى أنها تسعى لتحقيق أغر اض معينة

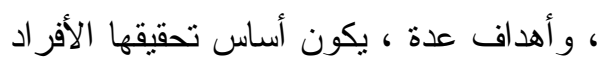
الذين بعملون بها ، وينتمون إليها ، و وعليـه

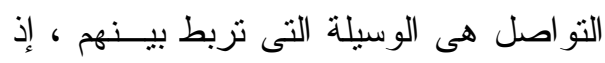

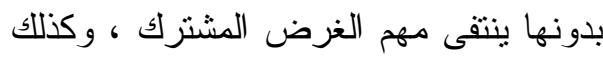

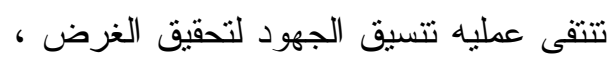

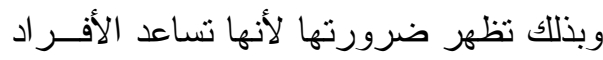
على معرفة ما يدور داخل المنظمة وخارجها

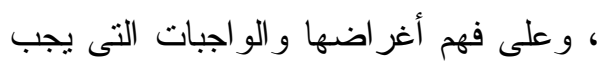

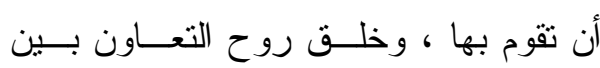

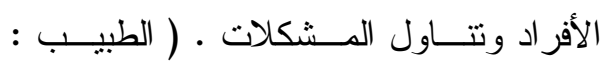
. ( IV . 1999

حيث تشكل عمليه التواصــل أهميـــة كبيرة فى المحيط المدرسى ، فهناك تو اصل

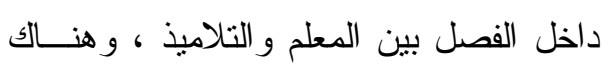

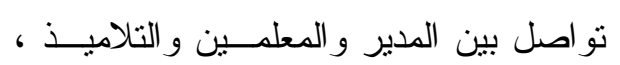

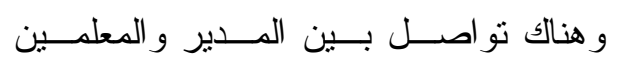
و التلاميذ و المجتمع المحلى و أولياء الامــور ولير
- الاتصسال له دور أساسي فـي تتــاول المشكلات المدرسية وطرق علاجها. - وسيلة فعالــة فــي احــداث التـأثير المطلوب على أفراد الأجهزة التتفيذية من أجل انجاز الأهداف المطلوبة . - احدى مهام المسؤولين فـــي الجهــاز الإداري داخل المدرسة . مهؤ

- يمثل وسيلة فعالة لممارســة القيــادة الادارية للسلطة و القوة .

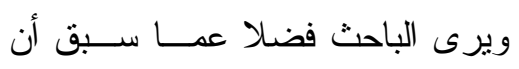
التو اصل المدرسى يهدف إلى تبادل الخبرات

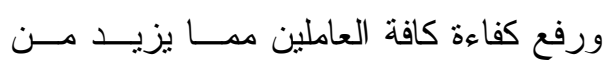

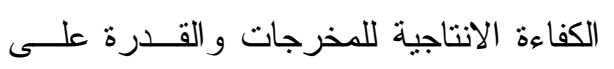
إنجاز الأعمال و المهام وتحقيق الأهداف الأنئ * أهمية التواصل المدرسي : تشكل عملية التو اصل أهمية كبيرة في

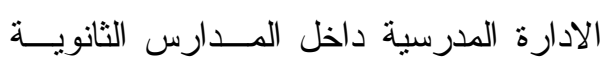

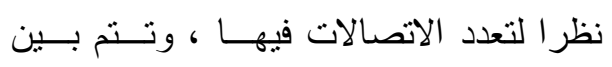

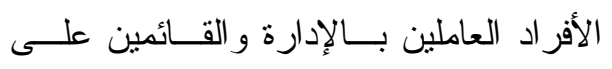

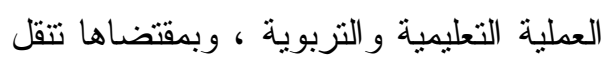

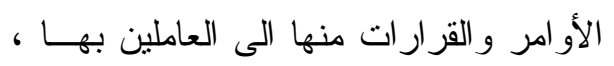
بهدف الآشر اف على نظام المدرسة ، فضلا

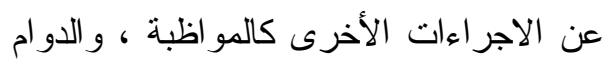

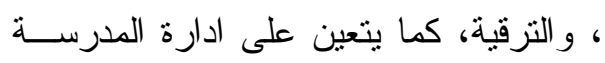
التواصل مع بعض المؤسسات البيئية الكائنة

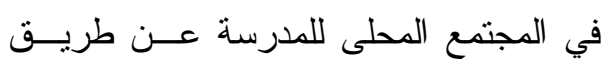




$$
\begin{aligned}
& \text { العلاقات بينهم و التوجيـهـ نحـــو } \\
& \text { إتخاذ القر ارات السليمة . }
\end{aligned}
$$

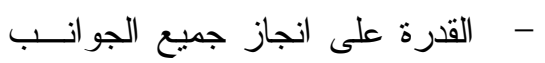

$$
\begin{aligned}
& \text { التدريسية و التزبوية و الإدارية التى جيع لهيت }
\end{aligned}
$$

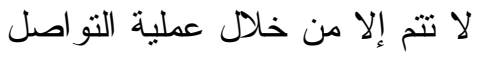

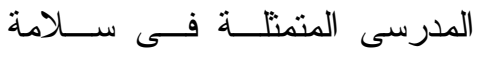

$$
\begin{aligned}
& \text { وسلامة مرور ونقل وتبادل الأراء } \\
& \text { و المقترحات و الأفكار و الخبر وات . ل } \\
& \text { " إن عملية التواصل المدرسى نساعد } \\
& \text { على الحد من ظهور الإثشاعات ونقل التراث } \\
& \text { الثقافي بين الأجيال وبث القيم وتحقيق أهداف }
\end{aligned}
$$

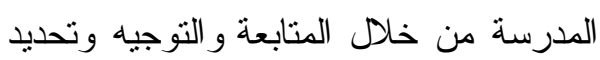

$$
\begin{aligned}
& \text { الو اجبات و المسؤوليات ، ومعرفه المستجدات }
\end{aligned}
$$

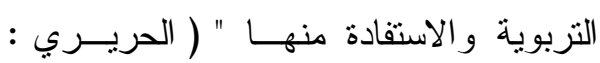

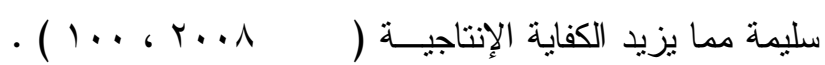

$$
\begin{aligned}
& \text { كما أن المدرسة لا يمكـن أن تقــوم }
\end{aligned}
$$

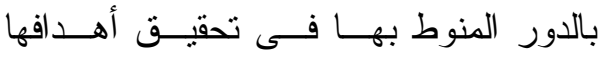

$$
\begin{aligned}
& \text { والاستمرار فى أداء مهامها الرئيسية إلا فى الهى } \\
& \text { خلال مقدرة العاملين بها من مدير ومعلمــين }
\end{aligned}
$$

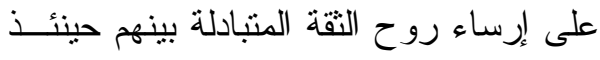

$$
\begin{aligned}
& \text { فى النقاط التالية: } \\
& \text { - عليه تحديد أهداف المدرسة مسـن } \\
& \text { خلا الوعى بالأهــــاف التربويــــة }
\end{aligned}
$$

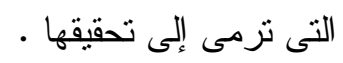

$$
\begin{aligned}
& \text { - - إختيار مدخلات العملية التعليميــة }
\end{aligned}
$$

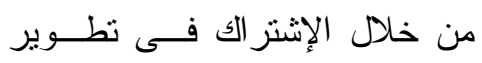

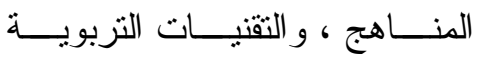

$$
\begin{aligned}
& \text { الاجتماعي }
\end{aligned}
$$




$$
\begin{aligned}
& \text { ب- تتمية العلاقات المنبادلـــة بــين }
\end{aligned}
$$

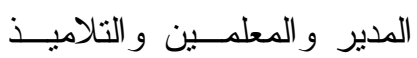

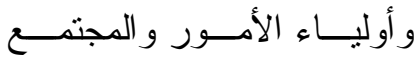

$$
\begin{aligned}
& \text { المحلى. } \\
& \text { ع - تحقيــق التفاعليـــة لوظـــائف } \\
& \text { الإدارة من تخطيط وتتظــيم } \\
& \text { وتوجيه ورقابـة وتتـسيق } \\
& \text { ل للعمل }
\end{aligned}
$$

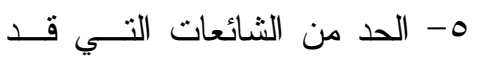

$$
\begin{aligned}
& \text { تحدث داخل البيئة المدرســية }
\end{aligned}
$$

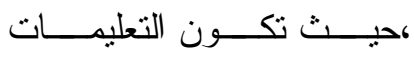

$$
\begin{aligned}
& \text { و الأوامر و الأفكار نابعة مــن } \\
& \text { المــدير و لا تعطـــى مجــالا } \\
& \text { ل اللثائعات . } \\
& \text { 1- تــــدعيم المركـــز التنافــسي } \\
& \text { للمؤسسة حيث التفهم لطبيعة } \\
& \text { العمل ،ومن ثم زيادة معرفـــة } \\
& \text { كل فرد لطبيعة عملــهـ جيــدا }
\end{aligned}
$$

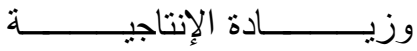

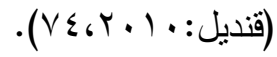

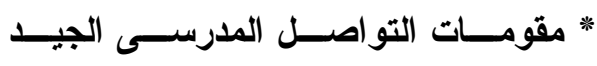

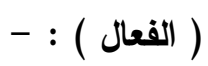

$$
\begin{aligned}
& \text { ومتابعة وتقويم • } \\
& \text { لطبيعة عملهم. توجيه } \\
& \text { و العمل على حلها . }
\end{aligned}
$$




\begin{tabular}{|c|c|}
\hline ( ) ) التفاعل الجيد ، حيث أن التواصــل & طبيعة الإنسان و الإتجاهــات التــى يكونهـــا \\
\hline الجيد من خلال تبادل التأثثر بـين & و الآر اء التى يعبر عنها ونجاحة وفثله فــى \\
\hline طرفى التو اصل و التفاعل مع البيئة & الحياة بمدى بر اعته فــى فــن التو اصــل ، \\
\hline المدرسية مما يؤدى إلــى تغذيـــة & 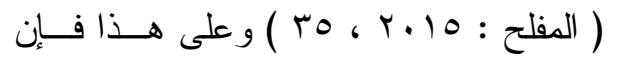 \\
\hline عكسية و إيجابية تتضح فى تحقبـق & المدرسة تسعى دائما لزيـــادة فعاليــة نظــــام \\
\hline الأهداف المنـشودة ـ ( محمـــ : & التو اصل بها ، و التقليل بقدر الإمكـــان مــن \\
\hline . ( I) $1, r \ldots$ & المعوقات و الحو اجز التى تحول دون تحقيـق \\
\hline (0 ) أن يكون التو اصل ملائم من حيــث & هذه الفعالية (صـبرى ، بــر : 9 ... ، ، \\
\hline الهدف و التوقيت ورسالة التو اصــلـ & 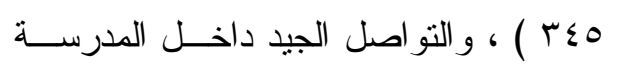 \\
\hline الوثيقة بــالموقف الــذى بـصدده & الثانوية لا بد له من عدد من المقومات التـى \\
\hline المستقبلون من المعلمين و التنلاميــذ & تزيد من فاعليته وكفاءته منها : \\
\hline و أولياء الأمور · & ( 1 ) التخطيط الجيد لعمليــة التواصــل \\
\hline ( 7 ) يجب إستخدام أكثر من وسيلة عنــد & وذلك من خلال تحديــــ الأهــــاف \\
\hline التو اصل ويجب أن تكون متقنهفـى & المنشودة كنها تم تحويـلـل المعنــى \\
\hline العـــرض و الكيفِــــة و الا تكـــــون & المقصود إلى كلمات أو رموز ، أو \\
\hline 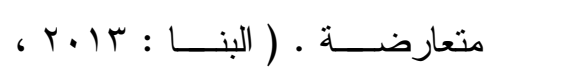 & إثشار ات ذوات دلالات معروفـــة ، \\
\hline$\cdot(I r r$ & وو اضحة ، وممددة ، ومتتاسـقة . \\
\hline ( السرعة فمدى السرعة أو البطء فى ) & 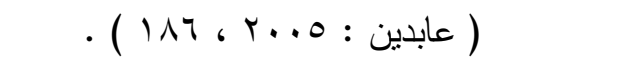 \\
\hline نقل المعلومات قد تكـــون للوســــلة & ( r ) أن تتسم الرسالة بالوضوح و السهولة \\
\hline المستخدمة فعند مقارنة التليفزيــون & 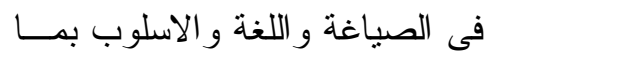 \\
\hline بالخطأ به ينبين أن عامل الــسرعة & يؤدى إلى فهم المستقبل لها ـ ( البنا \\
\hline مهم جداً فى نقل المعلومسـات فـى & $\cdot(\mid r), r \cdot \mid r:$ \\
\hline الوقت المناسب حيث نوفير الوقت & (r ) سلامة الوسيلة ومناســبتها أى يــنت \\
\hline و الجهد المساعدة على إتخاذ القرار. & أختيار الوسيلة المناسبة لموضــوع \\
\hline ( ماهر : 1999 ، بד ( ) فــدير & التو اصـــل بحيــث تتتاســـب مـــع \\
\hline المدرسة يجب عليه أن يحدد الوقت & خصائص المستقبل وتتوعها حسب \\
\hline المناسب للإتـــصال بــالم & الأهداف المطلوبة . \\
\hline
\end{tabular}


التواصل المدرسى بشكل سليم و التي تحقـق

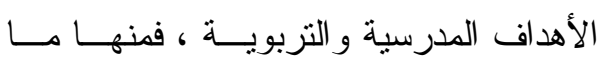

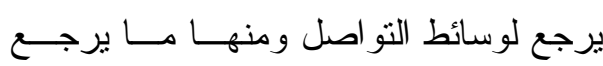

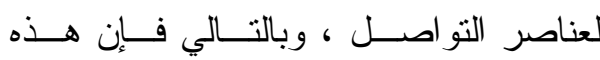

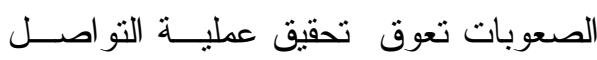

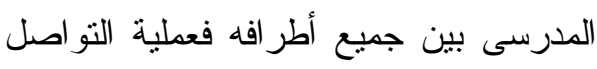
تتوقف فعاليتها على انتقال وتبادل المعلومات بين العاملين داخل المدرسة من المعلومــات

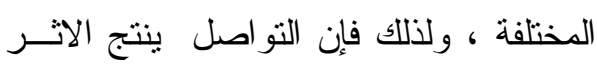

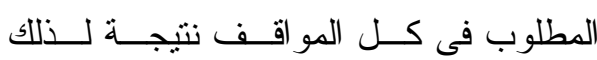

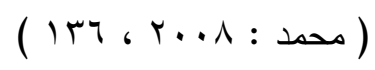

ومن الصعوبات التى تحول دون تحقبـق التواصل المدرسى بشكل يؤثر على عمليــة التفاعل داخل المجتمع المدرسى لـول ( ) (اللغة :

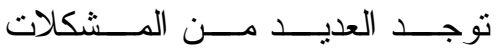

و المعوقات داخل المدرسة الثانوية بسبب عدم فهم معانى اللغة طريقة إستخدامها ، فتحسن عملية التو اصل المدرسى عن طريق كتابـــة

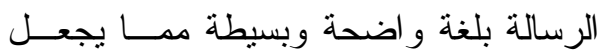

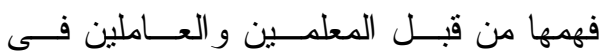

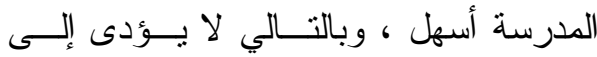

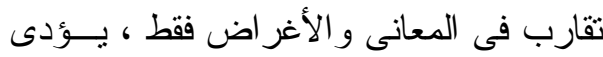
إلى الفهم المقصود من الرسالة بــدون أيـــة

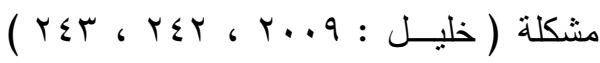
كما أن اختلاف المعاني بكلمات قد نؤدى إلى : لى ،

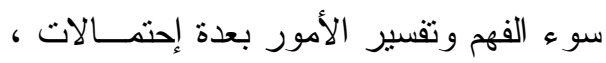

$$
\begin{aligned}
& \text { غيـر هم ، حيــث يــرتبط تفاعـلـ } \\
& \text { أعضاء المجتمــع المدرسـى مـــع }
\end{aligned}
$$

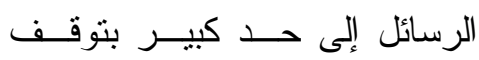

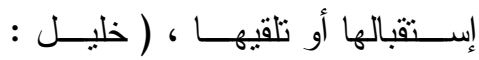

$$
\begin{aligned}
& \text {. ( } r \leqslant \wedge \text { r.. } q
\end{aligned}
$$

( ) ) تتظيم تدفق المعلومات ومتابعتها :-

إن تتظيم إعطاء الأوامر و التعليهـات

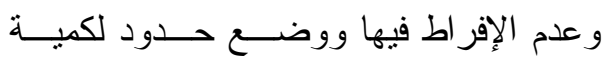
البيانات التى تتدفق من المدير إلى المعلمــين أو التلاميذ يمكن المسـتقبلين مــن الــتقهم

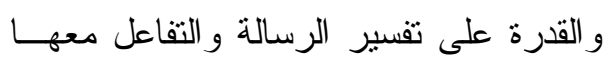
من أجل الوصول إلى المعنى المستهدف منها

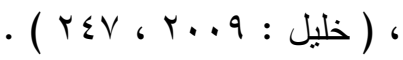
ومما سبق فــإن الباحسـث يـرى أن مقومات التواصل المدرسى الجيد هي العمل على تتمية مهار ات التو اصل نفسها وتتميــة روح الإبداع و الابتكار لدى العاملين فــضلاً عن تكوين علاقات إنسانية و إيجابيــة بيـــنهم وكذلك بينهم وبين أعضاء المجتمع الخارجي وكذلك أولياء الأمور ، بالإضـافة إلى نتميــة

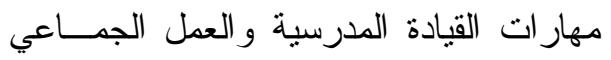
و العمل فى فرق لحل المشكلات . المحور الثاني :الصعوبات التى تحول دون تحقيق التواصل المدرسى : لـون

تعج المدرسة الثانوية بـالكثير مـن

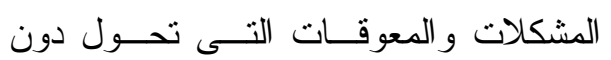


داخل المدرسة وسوء فهم مــضمون عمليــة التو اصل يتوقف على قدرة كل مــن المــدير و المعلمين على فهم كل ما يتم تداولة بيــنهم

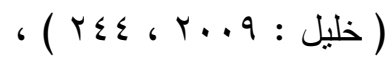
كما أن إختلاف عملية الإدرالك مـن دالخ فرد لآخر داخل المجتمع المدرسى لها الأثر الآدر الو اضح على كيفية التو اصــل مــن خــلهل سرعة البديهة التى تؤدى إلى سرعة الإنجاز

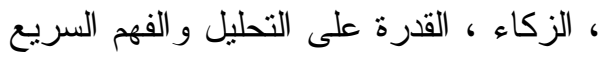
الخفيف ، ومن لا تتمتع بذللك يكون ذاء أتثر

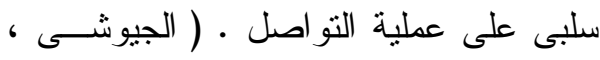

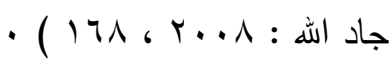
(r ) عدم توافر مهارات التواصل :إن إنخفـــاض مــستوى المهــــار ات التو اصلية لدى الإفر اد منل مهار ات التحـدث ومهار ات الإنــصات ومهــارة حسـسن إدارة

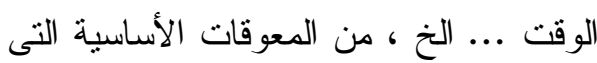

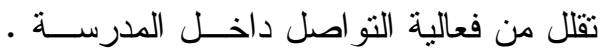

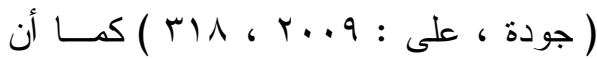
مدياً أو ناظر المدرسة الذى يكون لايه عــدم

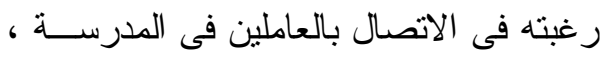

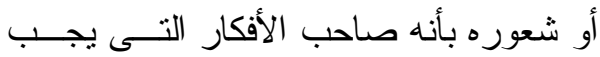

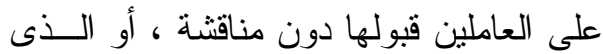

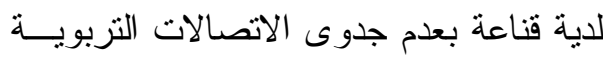

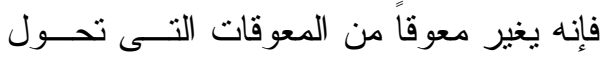

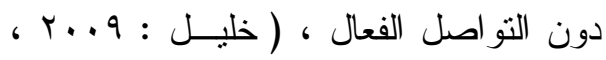

مما بشكل عائق على التو اصل ـ ( الجيوشى

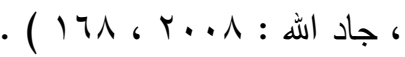
وكذلك عدم إستيعاب العاملين داخــل المدرسة للرسائل التو اصلية التى ترد إلــيهم وعدم فهمها من خلال الكلمات و العبـارات

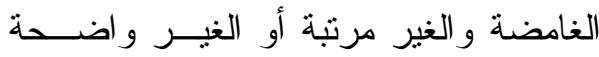

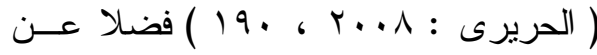
ذللك إن عدم فهم الكلمات و المعانى المكونــــة

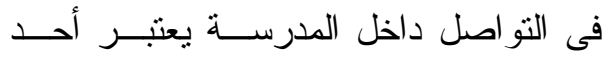
العوامل الهامة التى لها أثز كبير على فعالية الاتصال ، و الخطأ التى يقع فيه الفرد عــادة

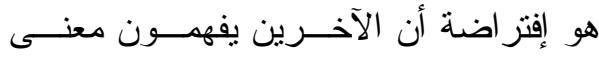
كلمات طالما هو يفهمها ، و هذا إقتز احة غير لإن

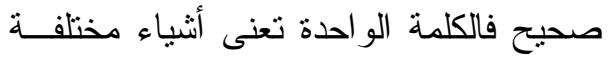

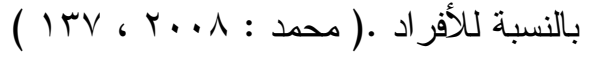
فسوء الفهم للكلمات غير المحددة ، و الغيــر متعارف عليها التى يستخدمها المرسل و التى تحمل معانى مغايرة لــدى المـستقبل فإنهـــا تؤدى بالتالى إلى نتيجة عكسية غير متوقعــة

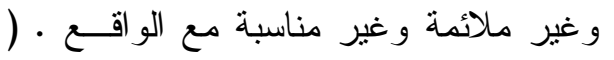

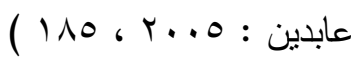
( القدرة على القهم : ( ) )

تختلف المعلمون فيما بينهم من حيــث قدرة كل منهم على الفهم الدقيق لما يقـال ،

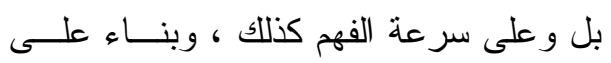

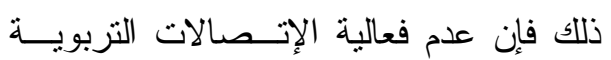




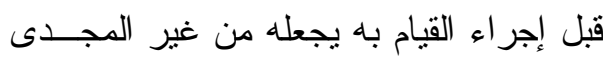

تختلف المدرسى عن بعضها الـبعض

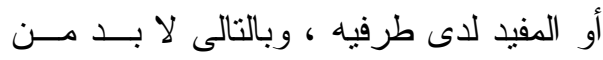

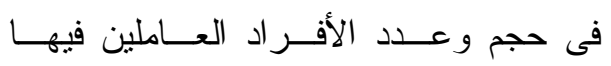

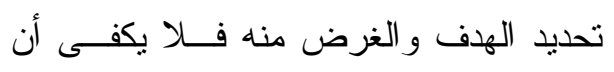

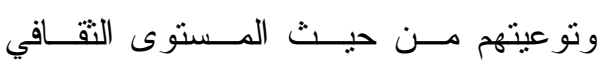
يكون المدير أو ناظر المدرسة واعياً لأهمية

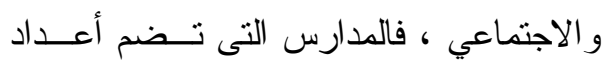

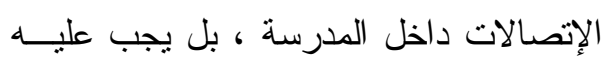

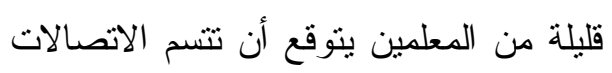

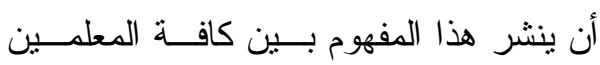

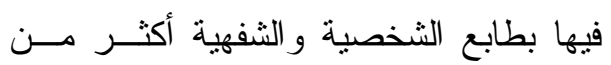

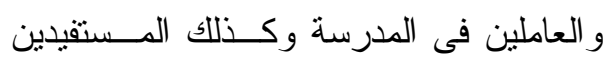

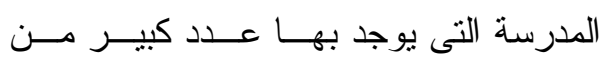
وبين أعضاء المجتمع المحلى و أولياء أمسـور

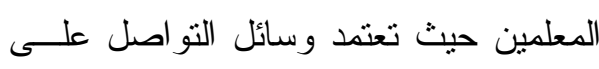

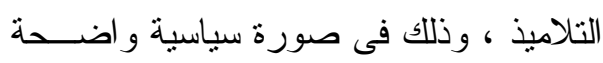
الرسائل الكتابية فـى إرســال المعلومــات

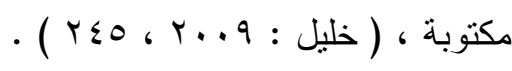

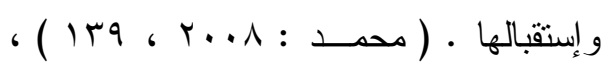

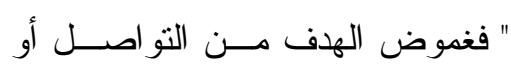
ولكل مدير أسلوبه الخاص فى استخدام طرق

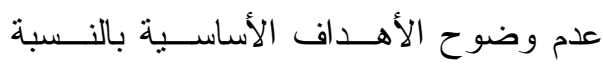

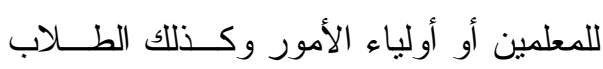
فإنه سوف يؤدى بالتالى إلــى نتــائج غيــر

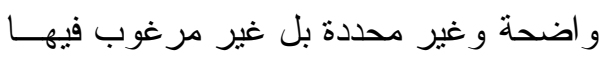

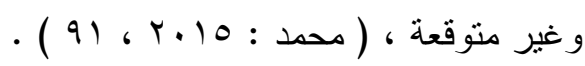
( 1 ) التباين فى الاتجاهات و القيم :

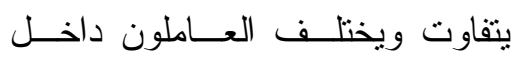
المدرسة فى خصائصهم وميولهم ورغباتهم ، وفى أسلوب تلقيهم للمعلومات و استيعابهم لها ، وفى المعانى و الدلات التى بصفونها عليها

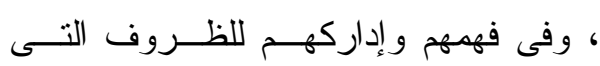
يعايشونها ، ومنل هذه الاختلافات تؤنز دون

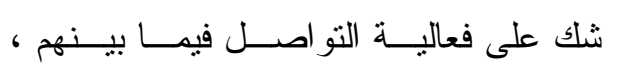

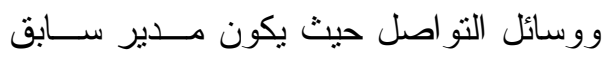

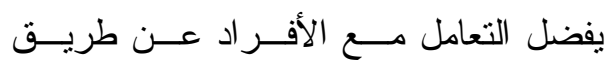

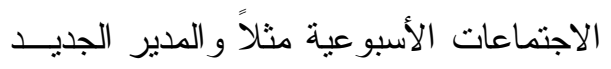
يفضل أن يكون الاتصال معه بواسطة لوحة

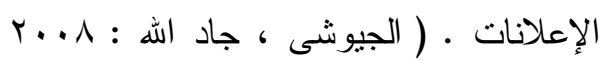

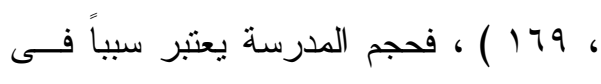
عدم إتاحة الفرصة للمعلمين و التلاميذ و أولياء

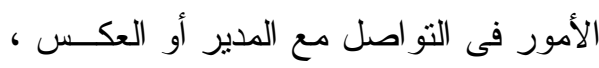

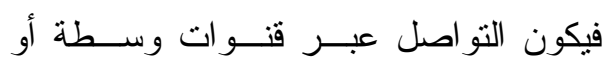

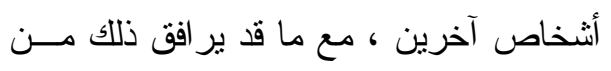

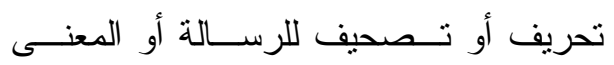

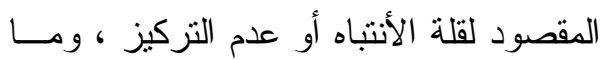

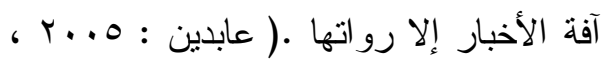


للارسالة بغض النظر عن ميوله ورغباتــهـ ،

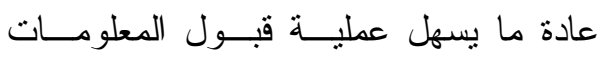

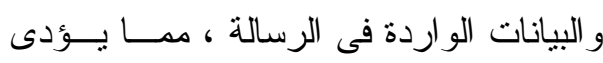
إلى زيادة فعالية التو اصل المدرسى ـ ـ ( خليل

$$
\text { . ( } r \leqslant r ، r \ldots q \text { : }
$$

$$
\text { ] [ ] ] الهيكل التنظيمي للمدرسة : - }
$$

هو عبارة عن مجموعة العلاقات التى

تربط بين مكوناته و أقسام المدرسة و الإدار ات

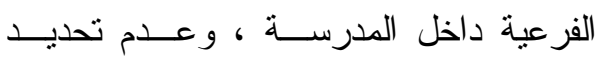
الإدار ات أو الأشخاص التى تقــوم بإرســـال البيانات و المعلومات وتلك تقــوم بإســنتقبال

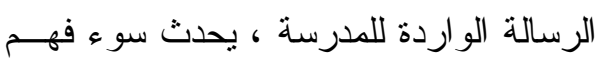
بين أعضاء المجتمع المدرسى نتيجـــة لعــدم وضوح مسئوليات و اختصاصات وسلطة كل عضو من أعضاء المجتمع المدرسى ( خليل

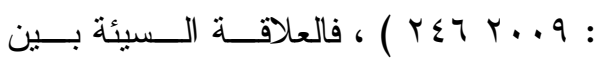
أعضاء المدرسة أنفسهم وبينهم وبين المــدير ، فاعلير

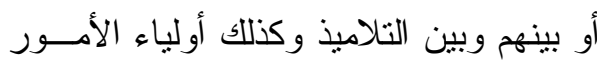

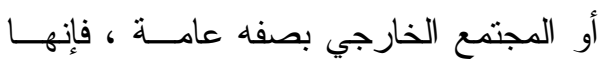
تعطى انطباع سيء عن المدرسة وذلك نتيجة

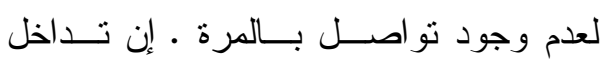
الاختصاصات وسو ء تحديد الهدف ، و إهمال الدقة فى توصيف الأعمال المختلفة الموجودة داخل المدرسة ، وكثرة الأعمال الروتينيـــة اليومية ، كما أن عدم فاعلية المدير الذى قد الد الدئ يلجأ إلى الوصاية على المعلمين و المرؤوسين المين

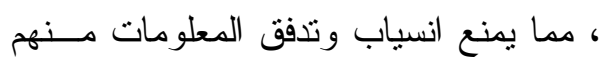

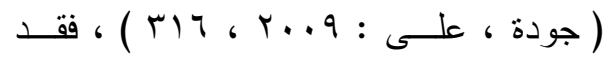

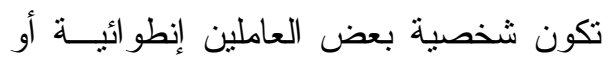
إنعز الية أو أنانية ، و هذا يعود إلى التنشئه أو لتون

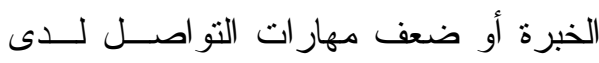
الفرد ، مما قد يحجب عملية الفهم بين طرفى الفي

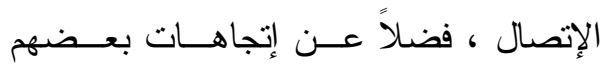

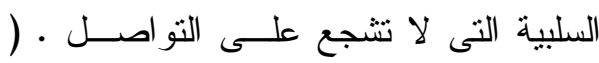

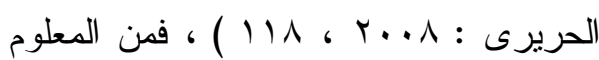

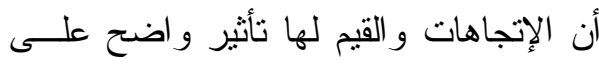

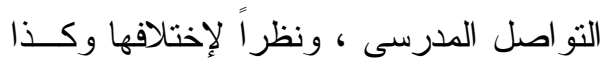

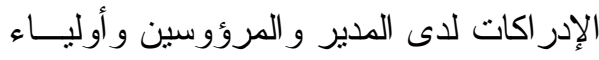

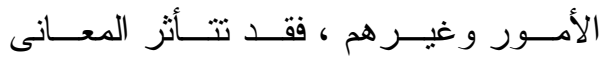
المقصودة تبعا لذلك ، وتعطى معان مغــايرة

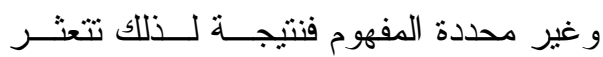

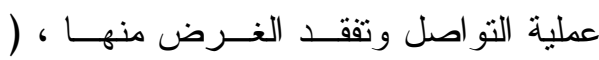

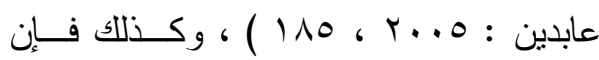

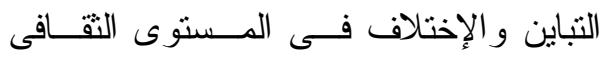
و المعرفى و الإدر اكى و الميـــول الثخــــية و الإتجاه الفكرى و العقيدة الدينية يؤثر بالطبع ولإدري

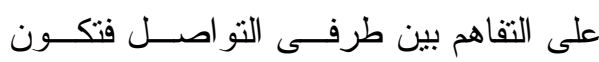

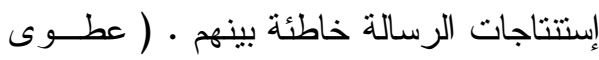

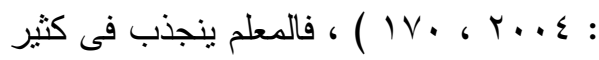

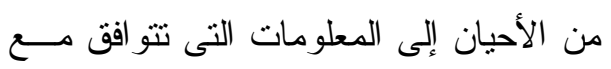

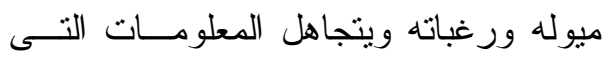
تتعارض مع ميوله ورغباته ، ولذلك فإن هذا

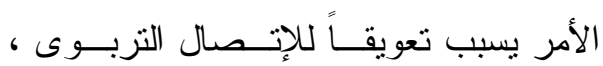
وبمعنى آخر فــإن موضـــوعية المــستقبل 


$$
\begin{aligned}
& \text { و عدم قبول التتوع والاخــتلاف فـى ألى }
\end{aligned}
$$

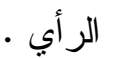

$$
\begin{aligned}
& \text { ه- شعور العاملين بالتميز فـــى المعاملـــة } \\
& \text { بينهم • } \\
& \text { 9- شعور العاملين بعـدم التوافـق فـى في }
\end{aligned}
$$

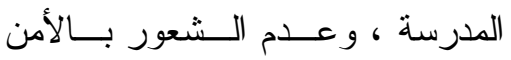

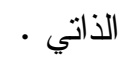

$$
\begin{aligned}
& \text { • 1- محاولــة المرســل تــرويج أفكــار } \\
& \text { ومقترحات تحد من رغبة المسـتقبل } \\
& \text { فى الانفتاح على التو اصل الفعال . } \\
& \text { المحور الثالث : بعض المتطلبات اللازمــة } \\
& \text { لمواجهة الصعوبات التى تحول دون تحقيق } \\
& \text { التو اصل المدرسى : } \\
& \text { "منطبات ادارية : } \\
& \text { 1- تبنى اساليب ادارية و انمــاط قياديـة } \\
& \text { تحقق ثقافة تتظيمية جيدة داخل المناخ ولئ }
\end{aligned}
$$

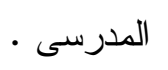

$$
\begin{aligned}
& \text { r- وضع بر امج تدريبية تؤهل العساملين }
\end{aligned}
$$

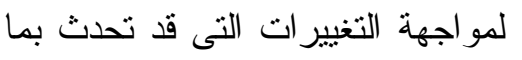

$$
\begin{aligned}
& \text { بحقق التنافسية . } \\
& \text { r- الاعتماد على الوســائل التكنولوجيـــة }
\end{aligned}
$$

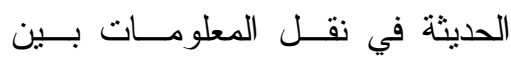

$$
\begin{aligned}
& \text { الوحدات الادارية المختلفــة د داخـلـل } \\
& \text { - المدرسة } \\
& \text { ع- استقدام مسـدربين مهـرة مسن ذوى } \\
& \text { الخبرة في تدريب العـاملين وتتميــة }
\end{aligned}
$$


"متطبات مادية :

rا- نوفير وسائل التواصــل المدرســى

الحديثة داخل المدرسة التى تساعد في لي

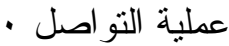

با - تـــوفير شــــكة نو اصـــل داخليـــة

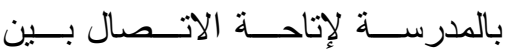

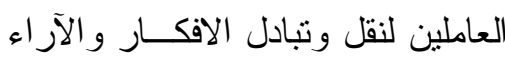

ووجهات النظر المختلفة .

ـ ا- الاهتمام بعمـل موقــع الكترونــى

للمدرسة يربط بين العاملين وكــذلك

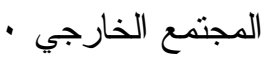

10 - عمل الصيانة اللازمة لكافة الاجهزة

17- الاستثمار الامثــل لكافــة المــوارد

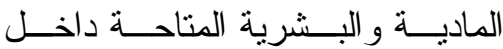

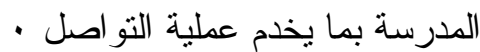

V ا - نوفير قاعدة من المعلومات و البيانات

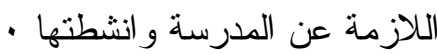

1 ا- تبـــادل الزيـــار ات بــين المدرســـة

و الددارس الاخرى لتبادل الخبر ات

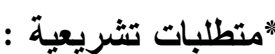

9 1- وضع خطة مستقبلية شاملة للمدرسة

تساعد على تتفيذ عمليات الادارة.

• r- التحديد الدقيق للمسئوليات و التخطيط

للمهام و التسيق لها.
قدر اتهم التو اصلية لإمكانية الاســفادة

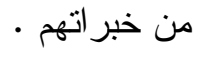

0- اتخاذ القرار ات المناسبة لدعم ابداعات

و افكار ومبتكرات العاملين ،وتوظيفها

$$
\text { لرفع مستوى الوعى لديهم • }
$$

؟- اتاحة الفرصــة لأعــضاء المجتمـع

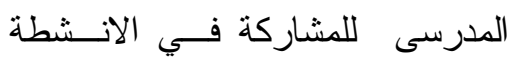

المختلفة داخل المدرسة وخارجها .

V- تتمية قدر ات العاملين علــى التحليـلـل

وتـــشيص المـــــلات و اختيــــار

المعالجات مــن مجموعــة البـــائل

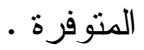

^- معرفة الاحتياجات المادية بالتعاون مع

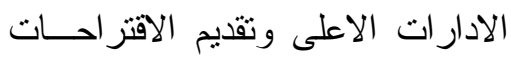

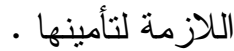

9- اتاحة الفرصة للمدرسة للتصرف في

كافة ابو اب الميز انية المعتمدة لها دون

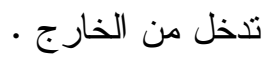

• 1- توفير نظام الحوافز لحث العساملين

على توظيــف تكنولوجيــا الاتــصال

الحديثة .

1 1- اجبار جميع العاملين علـى اجنيــاز

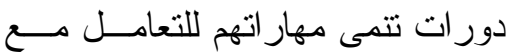

وسائل الاتصال الحديثة . 


$$
\begin{aligned}
& \text { ـ - الاسهام في حل المشكلات و المعوقات } \\
& \text { اب - لابد من مشاركة اعضاء المجتمـع }
\end{aligned}
$$

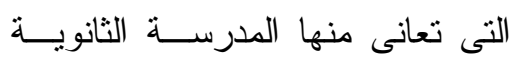

$$
\begin{aligned}
& \text { سواء التعليمية و الادارية. } \\
& \text { 0- تدريب اعضاء المجتمع المدرسى على }
\end{aligned}
$$

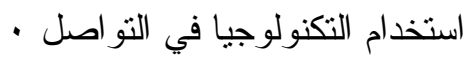

$$
\begin{aligned}
& \text { צ- تفعيل المشاركة المجتمعية في التعلــيم } \\
& \text { من خلا التو اصل الدائم بين المدرسة فئه }
\end{aligned}
$$

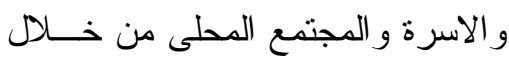

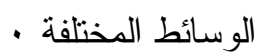

$$
\begin{aligned}
& \text { V- نطوير وسائل الاتــــال و التواصــل } \\
& \text { المختلفة داخل المدرسة سواء التقليدية } \\
& \text { او الالكترونية. } \\
& \text { ^- نشجيع التعاون بين العاملين بالمدرسة } \\
& \text { و المجتمع المحيط ل } \\
& \text { 9- توفير الــدور ات التدريبيــة للعــاملين } \\
& \text { داخل المدرسة وذلك من اجل تحسين }
\end{aligned}
$$

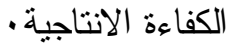

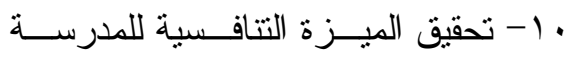

$$
\begin{aligned}
& \text { الثانوية من خلال العمل على تحقيــق } \\
& \text { فها طبقا للمعايير الدوليــة ومعـايير }
\end{aligned}
$$

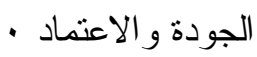

$$
\begin{aligned}
& 1 \text { 1- الاستفادة من الاتجاهات الحديثة فــي }
\end{aligned}
$$

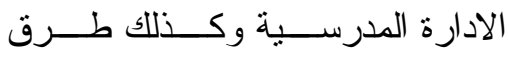

$$
\begin{aligned}
& \text { التدريس و التو اصل بشتى الوسائل ل } \\
& \text { rا- التصدي للتحديات المعاصرة للحـــ } \\
& \text { من سلبياتها و الاستفادة من ايجابياتها. } \\
& \text { المدرسية . - المرنية } \\
& \text { ل للأهداف و النتائج } \\
& \text { • العلاقات الانسانية العمان } \\
& \text { فيما بينهم بشكل جيد } \\
& \text { و اطر اف المدرسة الثانوية } \\
& \text { الثانوية }
\end{aligned}
$$

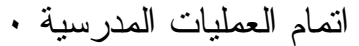




$$
\begin{aligned}
& 9 \text { 1-جدية العمل و التعاون بـين المجتمــع }
\end{aligned}
$$

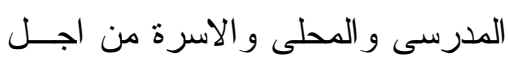

$$
\begin{aligned}
& \text { تفعيل عملية التو اصل . }
\end{aligned}
$$

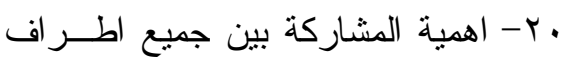

$$
\begin{aligned}
& \text { العمل المدرسى في صــنـع و اتخــاذ }
\end{aligned}
$$

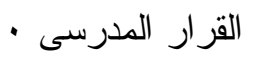$$
\text { اب- الاهنمام بتفعيل عمليــات التو اصـلـل }
$$$$
\text { داخل مجتمع المدرسة الثنانويــة بــين }
$$

$$
\text { كافة أطر افه . }
$$

r r- المرونة في تتفيذ اللو ائح و القـــوانين

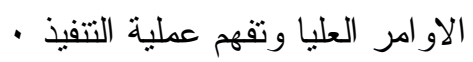

بץ- الاهنمام بترنيب وعمل الزيار ات بين

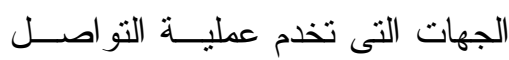

$$
\text { • المدرسى }
$$

ع ؟- ارتباط البيئة المدرسـية بــالمجتمع

الخارجي المحيط لتعبر عـنـ اهدافـــهـ

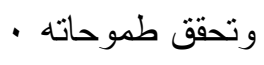

0ץ- استخدام الوسائل التواصلية المختلفة

الايجابية لتعزيز العمل المدرسى.

$$
\begin{aligned}
& \text { با - تتمية الاتجاهـات لـدى العـاملين }
\end{aligned}
$$

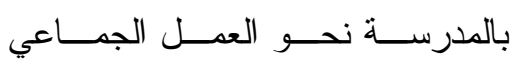

$$
\begin{aligned}
& \text { التعـــاوني و الاحـــساس بالمــسئولية }
\end{aligned}
$$

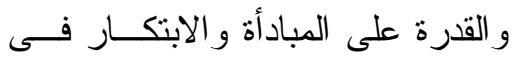

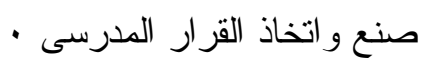

$$
\begin{aligned}
& \text { ـا- عرض تجارب الدول المتقدمة فـي } \\
& \text { التو اصل المدرسى للاستفادة منها . } \\
& \text { 10- توفير و اثتـر اء المدرســة بوســائل } \\
& \text { و التأهيل لاخول الجامعة }
\end{aligned}
$$

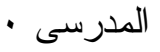

V ا ان تتبنى ادارة المدرسة نشر ثقافـــة

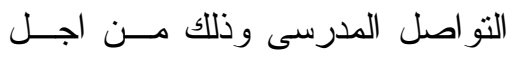

تحسين الاداء و المخرجات التعليميـــة

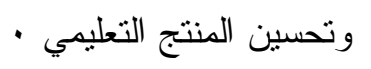

11- ان يكون لــدى اعـضاء المجتمــع

المدرسى ثقافة وقناعة بأهمية التطوير

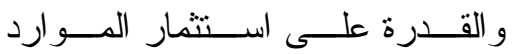

و الامكانات المتاحة بالبيئة المحيطـــة

لتحقيق اهداف المدرسة الثانوية · 
للتعليم ،رسالة ماجستير ،كلية التزبية

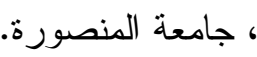

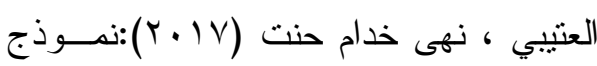

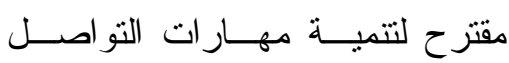

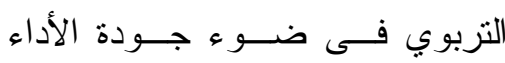

الوظيفي بين معلمي وموجهي التربية

الموسيقية بدولة الكويت ،مجلة كليــة

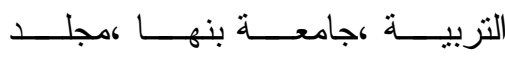

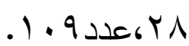

الدعس، زياد احمد خليل (9 . . r): معوقات

الاتصال و التواصـلـ التربــوي بــين

الدديرين و المعلمين بمدارس محافظة

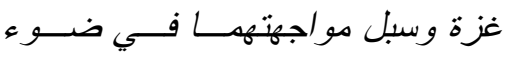

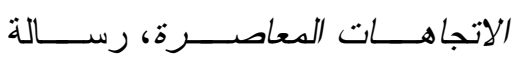

ماجستير، غير منشورة، كلية التزبية،

الجامعة الإسلامية بغزة.

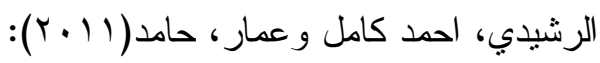

المشكلات المدرسية المعاصرة قضايا

وحلول، الجيزة، المكتبة الأكاديمية .

العجمي، محمــد حسنين ( (... ب): الإدارة

المدرسية الحديثة، القاهرة، دار الفكر

$$
\text { العربي. }
$$

محمد، فتحي عبدا لرسول (10 • ب): الإدارة

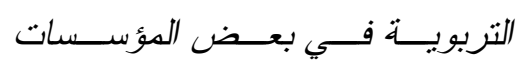

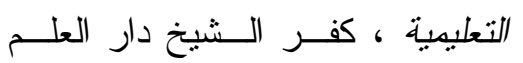

$$
\text { و الإيمان. }
$$

أبو سمعان، عماد احمـــ (11 (Y): درجــة

التعاون بين الإدارة الددرسية والإدارة

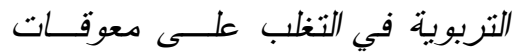

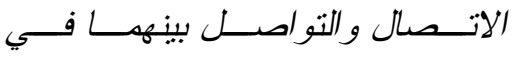

محافظات غزة، رسالة ماجستير غير

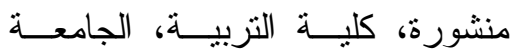

$$
\text { الإسلامية غزة. }
$$

http: //search.mandumah.com/Record/693071

آل سويدان، بندرحويزى عايض ابن حويزى

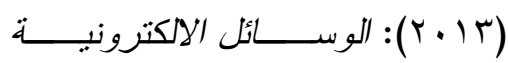

ودورها في تتمبية مهارات الاتــصال

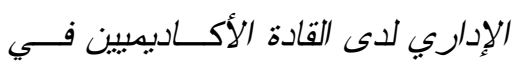

الجامعات السعودية، رسالة دكتور اه،

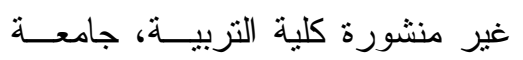

$$
\text { اليرموك، الأردن. }
$$

الجبر ،زينب على(ץ . . ץ):الادارة المدرسية الاردن

الحديثة من منظور علم النظم ، مكتبة

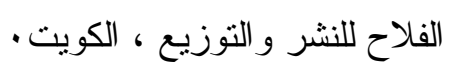

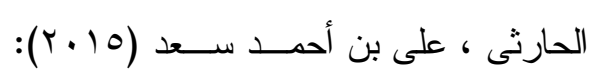

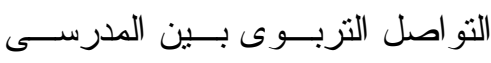

وأولياء الأمور وتطبيقاته المعاصرة ،

رسالة ماجستير ،كلية الدعوة و أصول

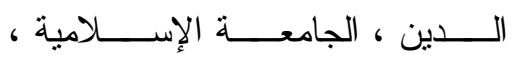

$$
\text { السعودية. }
$$

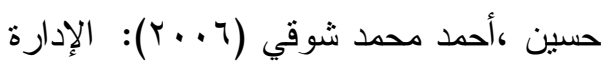

الذاتية مدخل لتذعيم مقومات المدرسة

الفعالة فى ضوء المعــايير القوميـــة 
خليل، نبيل ســد(9 . . ب)الادارة المدرســية

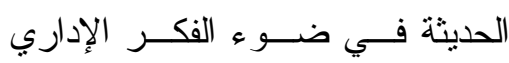

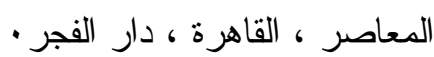

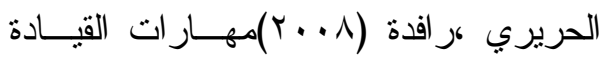
التربوية في اتخاذ القرارات الادارية ،

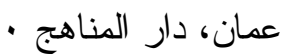

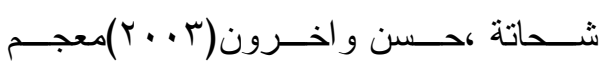

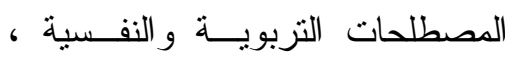

القاهرة ،الدار المصرية للطباعة .

البنا، هالة مصباح (r ( ب):الادارة المدرسية المعاصرة ، دار عمان ، صفاء للنشر

$$
\text { • و التوزيع }
$$

الجعب، نافذ سليمان(| (1) : درجة التزام

مديري مدارس وكالة الغوث بمدينـــة

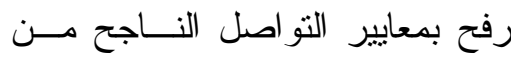
وجهة نظر المعلمين ،أعمال مــؤتمر بـائر

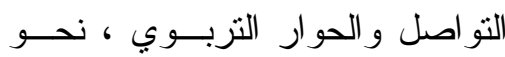

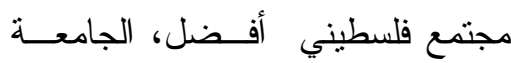

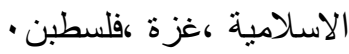

الطبيـــب، أحمــــــــــــــ99 (199):الادارة

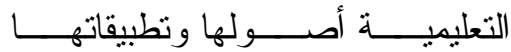

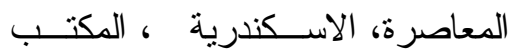
· الجامعي الحديث

المفلح ، خضرة عمر (10 + r): الاتـصال ،

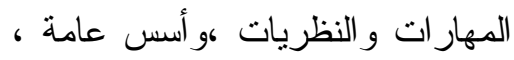
عمان، الحامد للنشر و التوزيع.

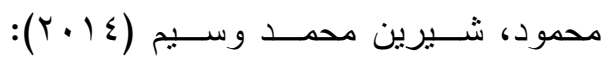
متطلبات تفعيـل الاتــصال الإدراري

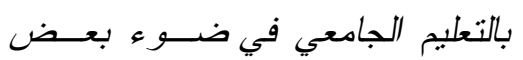

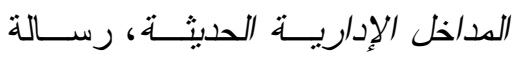
ماجستير غير منشورة، كلية التربية، جامعة المنصورة.

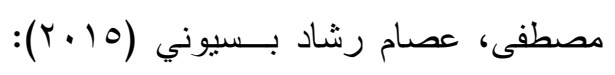

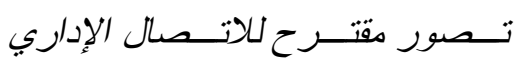

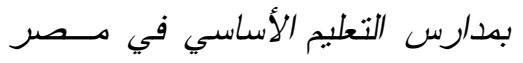
في ضوء الإدارة الالكترونية، رسالة ماجستير غير منشورة، كلية التزبية، جامعة كفر الثيخ.

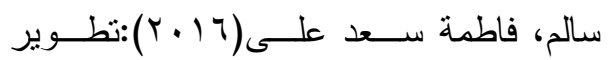
الاتصال الإداري فــى إدارة التعلــيم

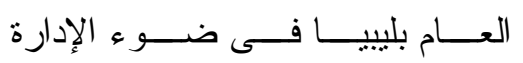
الالكترونية ،رسالة دكتور اه ، كليــة

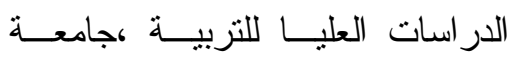

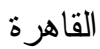
حسين ،طه عبـــالعظيم، حسـين ،ســلامة

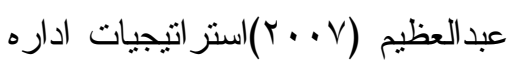

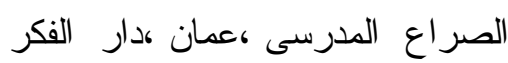

$$
\text { للنشر و النوزيع }
$$

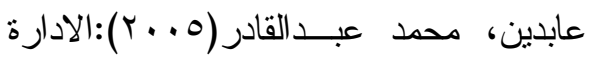
المدرســـية الحديثــــة ،،عمــــان ،دار

$$
\text { · الثروق }
$$

ادم، طلعت محمد(ع ا • r):الادارة المدرسية الميدانية ، الإسكندرية ، دار الوفاء. 
القاهرة ، طب، مركز و ايد سير فـيس

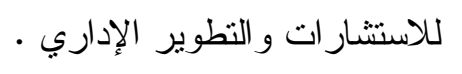

Cifim;(2016) Management of human resources in the educational colleges of the state universities in Turkey، International Journal of Environmental and Science Education ‘v1 n5.

Teska 'J: the super in tendency: effective leader ship through communication (Ed.M.. Eastern Michigan university ، 2003).

Zwijze-koning ‘karenh;de jong ، menno D.T(2009) ‘Auditing management practice in school; Recuring communications problems and solutions international journal of education management เv23n3.No. 8

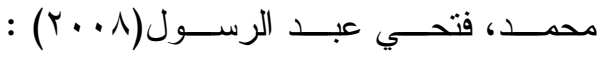

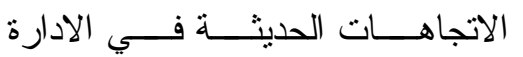

$$
\begin{aligned}
& \text { المدرسية ، الجيزة ، الــــار العالميـــة العدة }
\end{aligned}
$$

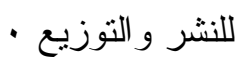

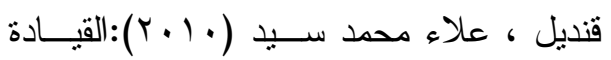

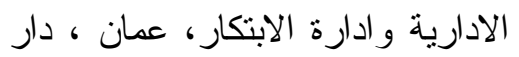

$$
\begin{aligned}
& \text { الفكر ناشرون وموزعون }
\end{aligned}
$$

ابر اهيم ، احمد ابر اهيم عبدالعليم ، محمود ،

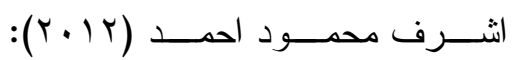

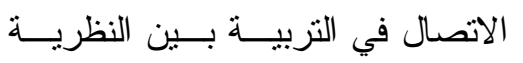

و التطبيق ، جدة ، خو ارزم العالمية . ل

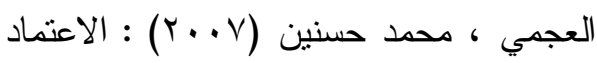

وضمان الجــودة الـشـاملة لمـــدارس

التعليم الثانوي العــام ، الاســكندرية،

دار الجامعة الجديدة - مائ

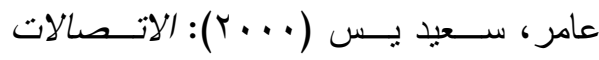

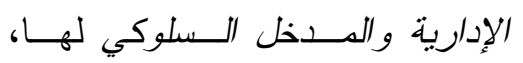

